\title{
The Functional Role of Prostate Cancer Metastasis-related Micro-RNAs
}

\author{
ULRICH H. WEIDLE ${ }^{1}$, ALEXANDRA EPP $^{1}$, FABIAN BIRZELE $^{2}$ and ULRICH BRINKMANN ${ }^{1}$ \\ ${ }^{1}$ Roche Pharma Research and Early Development, Roche Innovation Center Munich, Penzberg, Germany; \\ ${ }^{2}$ Roche Pharma Research and Early Development, Pharmaceutical Sciences, \\ Roche Innovation Center Basel, Basel, Switzerland
}

\begin{abstract}
The mortality of patients with hormone-resistant prostate cancer can be ascribed to a large degree to metastasis to distant organs, predominantly to the bones. In this review, we discuss the contribution of micro-RNAs (miRs) to the metastatic process of prostate cancer. The criteria for selection of miRs for this review were the availability of preclinical in vivo metastasis-related data in conjunction with prognostic clinical data. Depending on their function in the metastatic process, the corresponding miRs are up-or downregulated in prostate cancer tissues when compared to matching normal tissues. Up-regulated miRs preferentially target suppressors of cytokine signaling or tumor suppressorrelated genes and metastasis-inhibitory transcription factors. Down-regulated miRs promote epithelial-mesenchymal transition or mesenchymal-epithelial transition and diverse pro-metastatic signaling pathways. Some of the discussed miRs exert their function by simultaneously targeting epigenetic pathways as well as cell-cycle-related, antiapoptotic and signaling-promoting targets. Finally, we discuss potential therapeutic options for the treatment of prostate cancer-related metastases by substitution or inhibition of miRs.
\end{abstract}

In $2017,160,000$ new cases of prostate cancer (PC) were diagnosed in the US and an equal number in the EU with

This article is freely accessible online.

Correspondence to: Ulrich Brinkmann, Roche Innovation Center Munich, Nonnenwald, 82377 Penzberg, Germany. Tel: +49 8856604753, e-mail: ulrich.brinkmann@ roche.com; or to Ulrich H. Weidle, Tel: +49 15114096083, e-mail: weidle49@t-online.de

Key Words: In vivo metastasis models, interference with signaling networks, miR substitution and inhibition, prognostic aspects, prometastatic pathways, target validation, review.
27,000 patients dying due to metastatic PC in the US and the EU (1). Localized disease can be potentially cured by therapies such as surgery and radiation, but in some patients, the disease progresses despite these therapies (2). Androgendeprivation therapy leads to long-lasting responses between 2 and 3 years, however the disease inevitably progresses to castration-resistant prostate cancer (CRPC) that is associated with metastatic disease and poor prognosis. Over the past 5 years, five drugs have been approved for treatment of CRPC (2). These are cabazitaxel, a taxane-based cytostatic; radium 223, an $\alpha$-emitter; enzalutamide, a small-molecule androgen receptor (AR) antagonist; abiraterone, a blocker of de novo synthesis of androgens; and Sipuleucel, a dendritic cell-based immunotherapy (3).

The recent genetic classification of PC has revealed seven subtypes and new molecular targets for molecular intervention such as v-ets erythroblastosis virus E26 homolog (ETS) family transcription factor-based fusion proteins as well as mutations in speckle-type $\mathrm{POZ}$ protein $(S P O P)$, forkhead protein A1 (FOXA1) and isocitrate dehydrogenase 1 (IDHI) (4). The serine protease inhibitor Kazal-type 1 (SPINK), which is up-regulated in ETSrearrangement-negative tumors, is also being pursued as a new target for treatment of CRPC (5). Nucleic acid-based therapy is another approach for treatment of CRPC. Custirsen, a second-generation phosphorothioate antisense oligonucleotide targeting clusterin mRNA is presently undergoing phase III clinical studies in combination with chemotherapy in patients with $\operatorname{CRPC}(6,7)$. Clusterin is upregulated in patients with CRPC and functions as an ATPindependent molecular chaperone with anti-apoptotic function through inhibition of pro-apoptotic B-cell lymphoma virus-associated $\mathrm{X}(\mathrm{BAX})$ by altering its conformation $(6,7)$. In this review, we focus on micro-RNAs (miRs), another class of targets for nucleic acid-based therapy, their role in PC metastasis, and their potential function as therapeutic targets. We exclusively discuss miRs 
validated by in vitro and in vivo preclinical experiments and exclude those which are in earlier stages of preclinical development.

\section{Process of PC Metastasis}

PC metastasis can be dissected into several functional steps (8-12). The metastatic process starts with cancer cells at the tumor edge undergoing epithelial-mesenchymal transition (EMT) associated with acquiring invasive properties, intravasation as single cells or multicellular aggregates, activation of survival programs, protection against attack by immune cells and finally extravasation and colonization of distant organs with a high preference for bone (12). Stromalderived factor $1 / \mathrm{C}-\mathrm{X}-\mathrm{C}$ receptor 4 (SDF1/CXCR4) interactions are a prerequisite for bone tropism of PC cells and for access to metastatic niches in the bone marrow (13). The disseminated tumor cells undergo bi-directional interactions with bone-forming cells (osteoblasts), bonedegrading cells (osteoclasts) and other cells in the tumor microenvironment. The metastatic niche is populated by androgen-independent and chemotherapy-resistant cancer stem cells (CSCs), which are supported by mesenchymal cells with respect to growth and survival, while CSCs contribute to recruitment of cancer-associated fibroblasts (14). Furthermore, angiogenesis is essential for the outgrowth of bone metastases. Osteoblastic, osteoclastic and mixed lesions have been identified as PC-related metastases due to the imbalance of osteoblast-mediated bone formation and osteoclast-mediated bone resorption $(9,10)$. Very often, bone metastases display both osteoblastic and osteolytic elements.

An essential component of bone destruction and osteolytic metastasis is the axis formed by the receptor activator of nuclear factor-kB (NFkB)/receptor activator of $\mathrm{NFKB}$ (RANK)/RANK ligand (RANKL)/osteoprotegerin OPG) and members of the tumor necrosis factor (TNF)/tumor necrosis factor receptor (TNFR) superfamily $(9,11)$.Tumor cellsecreted parathyroid hormone, parathyroid hormone-related protein, interleukin1 (IL-1), IL-6 and RANKL mediate activation of osteoclasts and thus facilitate bone destruction $(9,11)$. RANK/RANKL interactions result in the activation of NFkB signaling and stimulate final effectors of osteolysis such as carboanhydrase II, H+ ATPase and cathepsin K. A vicious cycle is initiated during which osteolysis factors such as transforming growth factor $\beta$ (TGF $\beta$ ), insulin-like growth factor 1 (IGF1) and $\mathrm{Ca}^{2+}$ are released, which promote tumor cell proliferation and production of parathyroid hormonerelated protein. Osteoblastic metastases are stimulated by factors, which promote osteoblast activity such as fibroblast growth factor (FGF), RANKL, platelet-derived growth factor, IGF1, and endothelin $1(9,11)$. TGF $\beta$ is activated from latent TGF $\beta$; IGF1 can be released from inhibitory
IGF binding proteins; and the osteolytic factor parathyroid hormone-related protein can be inactivated by proteases such as urokinase (9). Bone metastasis is associated with skeleton-related events such as intractable pain, bone fractions, spinal cord suppression, neurological deficits and paralysis (15).

\section{Micro RNAs}

miRs are small noncoding RNAs with a length between 18 and 25 nucleotides. They are transcribed in the nucleus as primary pre-miRs that are capped, spliced and polyadenylated. Thirty percent of miRs are processed from introns of protein-coding genes, the others are encoded by dedicated loci (16-18). Primary pre-miRs are cleaved by a complex called the microprocessor to 60- to 70-nucleotide hair-pin looped pre-miRs, which are exported to the cytoplasm by exportin 5 and subsequently are processed by multi-protein complex DICER to produce mature miRs. One strand of the mature miR (guide strand) is loaded into the miR-induced silencing complex to target mRNA by sequence complementarity. This interaction results in gene suppression by targeted mRNA degradation or translational repression in processing bodies (18). More than 1,000 miR genes have been identified and a single miR can target hundreds to thousands of mRNAs, while a single gene can be targeted by multiple miRs (19). Therefore, miRs can function as regulators of complex signaling networks.

The importance of miRs in cancer was demonstrated by correlating the deletion of miR15/miR16 with chronic lymphocytic leukemia and its induction in a mouse model by deletion of miR15/miRl6 (20). Furthermore, miRs are involved in pro-oncogenic and tumor-suppressive pathways in a context-dependant manner (21). The crucial role of miRs in metastasis has been demonstrated for breast cancer (22, 23), ovarian cancer (24), colorectal cancer (25), and hepatocellular carcinoma (26). Here, we focus on the role of specific miRs involved in the metastatic process of PC.

\section{Prostate Cancer Cell Lines and In Vivo Models}

In this review, we describe PC metastasis related miRs which have been validated in at least one in vivo model. We excluded miRs with metastasis-related prognostic impact, but lacking in vivo validation in a PC-related metastasis model.

Several subtypes of PC such as adenocarcinoma, transitional cell, squamous cell and small cell carcinoma (neuroendocrine) have been described (27). The most abundant subtype is prostate adenocarcinoma $(\geq 90 \%)$ and consequently most PC cell lines used for in vitro and in vivo studies correspond to this phenotype. The most commonly used PC cell lines are DU-145, PC3, LNCaP, C42B, LAPC4, $\mathrm{VCaP}$ and $22 \mathrm{Rv}$ as well as BPH1, PIN, RWE-1,2 as 


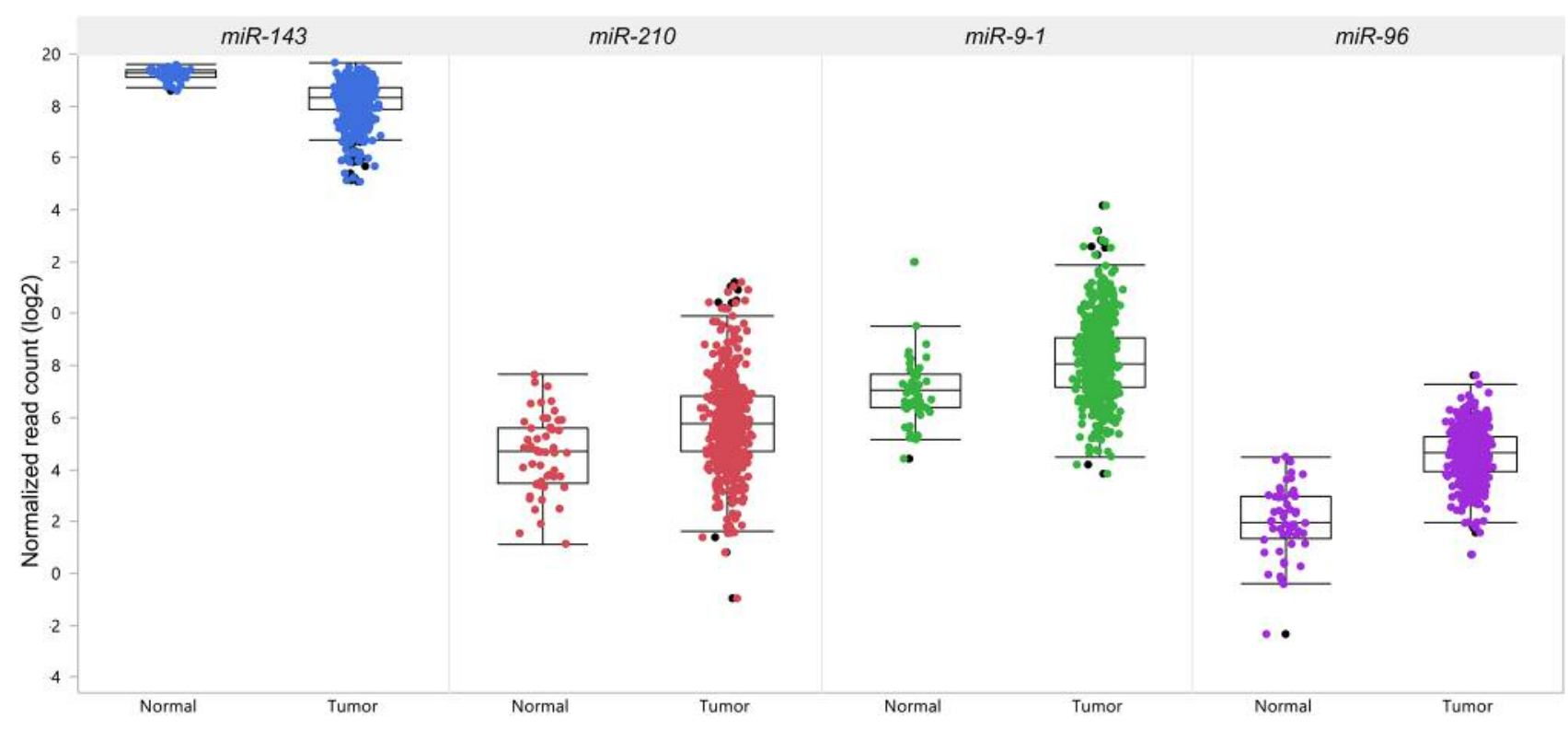

Figure 1. Steady-state levels of miR-143, miR-210, miR-9 and miR-96 in prostate cancer and corresponding normal tissues. A total of 52 matched normal prostate and 495 prostate tumor samples were investigated. Expression as measured by RNA sequencing in The Cancer Genome Atlas prostate adenocarcinoma cohort are shown as $\log _{2}$ Normalized Read Count values as provided by Broad's FIREHOSE service. Expression data are shown as box plots where the black line represents the median value and the black rectangles indicate the upper and lower 25\% quartiles. Therefore, $50 \%$ of all data points are included in the black rectangle. All other data points, except for outliers, are located within the upper and lower whiskers.

immortalized prostate cells. The generation and functional characterization of these cell lines is described in detail in (28). For functional in vivo metastasis-related studies, several standard in vivo models are used (28-30). Hematogenous metastasis-mimicking models are based on either the injection of PC cells into the tail vein of mice and monitoring the development of lung metastases, or on intracardiac tumor cell inoculation and following-up of their metastasis to distant organs. Spontaneous metastasis can be assessed by subcutaneous implantation or by orthotopic prostatic implantation. Injection of PC cells into the bones mimics the growth of PC cells in the bone microenvironment, but is not a model of metastasis per se $(28,29)$. Vossicle models are based on implantation of vertebrae from transgenic mice together with PC cells into athymic mice to study the effects of genetic alterations in the tumor microenvironment on tumor development and metastasis $(28,29)$. The transgenic adenocarcinoma of the mouse prostate (TRAMP) model was developed as the first in vivo transgenic model with spontaneous $\mathrm{PC}$ metastasis $(30,31)$. In this model, SV40 large T-antigen is expressed in prostate cells under the control of the rat probasin promoter. Metastasis to the lymph nodes, the lungs and occasionally to the kidney, adrenal glands and bones has been observed in this model.

\section{miRs Promoting PC Metastasis}

SOCS-targeting miRs (miR-9, miR-194, miR-210). miR-9 is up-regulated in $75 \%$ of patients with $\mathrm{PC}$ in comparison to corresponding normal tissues (33) and Figure 1. miR-9 promoted the growth and invasion of the PC cell line M12. Subcutaneously injected M12 cells expressing a $m i R-9$ sponge showed reduced tumor growth. Intraprostatic injection of $m i R$ 9 sponge expressing M12 cells revealed no metastatic sites in contrast to the control cell line (33). Cadherin 1 (CDH1) and SOCS5 were identified as direct targets of miR-9 (33). Cleavage of CDH1 leads to accumulation of $\beta$-catenin in the nucleus, driving transcription of survival factors such as cMYC and cyclin D1 (34). c-MYC induces additional miR-9. The second $m i R-9$ target, SOCS5, prevents phosphorylation of Janus kinase and signal transducer and activator of transcription 3 (STAT3) (35) (Figure 2A).

Serum levels of $m i R-194$ are higher in men with CRPC than those in men with localized disease (36). miR-194 is induced by transcription factor GATA binding protein $2(37,38)$ and PC 3 cells ectopically expressing $m i R-194$ showed significantly enhanced cell invasion in the chorionic allantoic membrane assay and exhibited spontaneous metastasis to visceral organs such as kidney, lung, liver and spleen, whereas control PC3 cells remained contained in the prostate (36). SOCS2, a 
ubiquitin ligase, was identified as a direct target of miR-194 (36). Inhibition of SOCS2 induced expression of prometastatic genes such as Fms-like tyrosine kinase 3 (FLT3) and $J A K 1$ through activation of extracellular regulated kinase (ERK)-and STAT3 signaling $(39,40)$ (Figure 2A).

$m i R-210-3 p$ is elevated in PC, particularly in bonemetastatic $\mathrm{PC}$, and promoted EMT after transfection into $\mathrm{VCaP}$ and C42B PC cells (41) and Figure 1. Silencing of $m i R$ $210 p$ in PC3 cells reduced tumor burden and metastatic sites in bone after intracardial injection (41). $m i R-210-3 p$ activated $\mathrm{NF}-\mathrm{kB}$ signaling and the expression of metastasis-related genes such as twist family bHLH transcription factor 1 (TWIST1), matrix metalloproteinase 13 (MMP13) and IL11 (41). The molecular basis for activation of NFKB signaling is the direct inactivation of SOCS1 and TNF $\alpha$-induced protein 3 interacting protein 1 (TNIP1), both inhibitors of NFKB signaling (42-44). SOCS1 suppresses NFKB signaling by binding to DNA-bound $\mathrm{p} 65$ and induces its degradation (45). TNIP1 suppresses NFkB signaling through deubiquitinylation of NFkB essential modulator (44) (Figure 2B).

miRs targeting tumor-suppressor genes (miR-96, miR-154, $m i R-379$ and miR-409). Several observations have demonstrated the involvement of miR-96 in PC invasion and metastasis. miR-96 is transcriptionally regulated through nuclear epidermal growth factor (EGFR) and directly targets tumor-suppressor transcription factor ETS variant 6 (ETV6) (46-49). In several hematological malignancies, ETV6 is inactivated by a mutation (50). ETV6 is inversely correlated with EGFR-miR-96 signaling in clinical samples. A reduction of metastasis to the brain and bone has been observed after cardiac injection of RasB1 PC cells ectopically expressing ETV6 (46). Furthermore, miR-96 directly targets forkhead box O1 (FOXO1), a tumor-suppressive transcription factor (50). FOXO1 enhances apoptosis, reduces proliferation and inhibits androgen-dependent and -independent activity of AR (51-54). In addition, it has been shown that TGF $\beta$ induces miR-96 through SMAD family-dependent transcription and inactivation of AKT serine/threonine kinase 1 substrate 1 (AKT1S1) mRNA, a negative regulator of $m i R-96$ (55). $m i R$ 96 was shown to promote bone metastasis in a PC model (55) (Figure 2B). In addition, dose-dependent regulation of hypoxia-induced autophagy by $m i R-96$ has been documented (56). miR-96 was found to be up-regulated in PC samples in comparison to matched normal prostate tissues (Figure 1).

Delta-like1 homolog deiodinase iodothyronine 3 (DLKDIO3) cluster-related miRs $m i R-409-3 p, m i R-5 p, m i R-154^{*}$ and $m i R-379$ are activated in embryonic stem cells (57). miR409$3 p$ and $m i R-409-5 p$ were found to be activated in PC with high Gleason scores and expression levels of $m i R-409-3 p$ correlated with disease-free survival $(57,58) . m i R-154^{*}$ and $m i R-379$ were also found to be highly expressed in PC and miR-379 expression correlated with progression-free survival in patients.
miRs of this cluster share a couple of common functional features with subtle differences which are not discussed in detail here. Functional studies have identified them as mediators of EMT-related changes of PC cells towards spindleshaped cells, reduced expression of E-cadherin and increased expression of vimentin $(57,58)$. Ectopic expression of $m i R$ 409-3p/5p in the prostate gland transformed normal prostate epithelial cells, and promoted tumorigenicity, EMT and stemness in vivo (58). Mice inoculated intracardially with metastatic ARCaP cells had $100 \%$ incidence of bone metastasis, whereas in mice bearing cells transfected with a $m i R-409-3 \mathrm{p} / 5 \mathrm{p}$ inhibitor did not develop metastases within 15 weeks. Similarly, inhibitors of $m i R-154 *$ reduced bone and soft-tissue metastases in the ARCaP model (58). Several tumorsuppressor genes are inhibited by miRs of this cluster: stromal antigen 2 (STAG2) $(59,60)$, ras suppressor protein 1 (RSU1) (61), retinoblastoma like 2 (RBL2) (62), nitrogen permease regulator like 2 (NPRL2) (63), polyhomeotic homolog 3 (PHC3), a polycomb group protein (64), von Hippel-Lindau tumor suppressor, an E3 ubiquitin ligase (65) and $S M A D 7$, a signal transducer of TGF $\beta$ signaling (66). Several prometastatic pathways are activated: hypoxia-inducible factor- $1 \alpha$ (HIF1 $\alpha$ ) through inhibition of its tumor suppressor E3 ubiquitin ligase function (65), inhibition of NPRL2 activates RAS and AKT signaling (63), RBL2 degradation induces the E2F pathway (62), deactivation of STAG2 promotes aneuploidy $(59,60)$ and several miRs of the cluster promote activation of polycomb proteins and osteoblastic pathways (57). The mode of action of $m i R-154, m i R-379, m i R-409-3 p$ and $m i R-409-5 \mathrm{p}$ are summarized in Figure 3.

Targeting of intercellular adhesion molecule-1 (ICAM1) by miR-296-3p. Clinical tissue microarrays have revealed frequent up-regulation of $m i R-296-3 \mathrm{p}$ in PC patients and concomitant down-regulation of ICAMI (67). Knock-down of $m i R-296-3 \mathrm{p}$ in M12 PC cells reduced pulmonary metastasis in a model of experimental metastasis in nude mice (22). $m i R-296-3 p$ inhibits ICAM1 by directly targeting its 3'UTR and is pivotal for the metastasis of PC9 cells to the lungs, probably by enhancing survival of circulating tumor cells by mediating resistance to natural killer (NK) cells (67). The described in vivo effects were abolished by a natural killer cell-eliminating anti-sialo GM1 antibody (67). ICAM1 has been identified as a co-stimulator of natural killer cell-mediated cytotoxicity $(68,69)$.

$A R$ as a target of miR-301a. miR-301a is a predictor of PC metastasis, which is induced in tumor cells by adipocytes (70). It was shown that PC recruits more adipocytes than normal prostate tissues and in vitro enhanced pre-adipocyte recruitment increases PC cell invasion (70). Overexpression of miR-301a enhanced lung metastasis of LNCaP and PC3 cells after subcutaneous implantation into nude mice (70). 
A
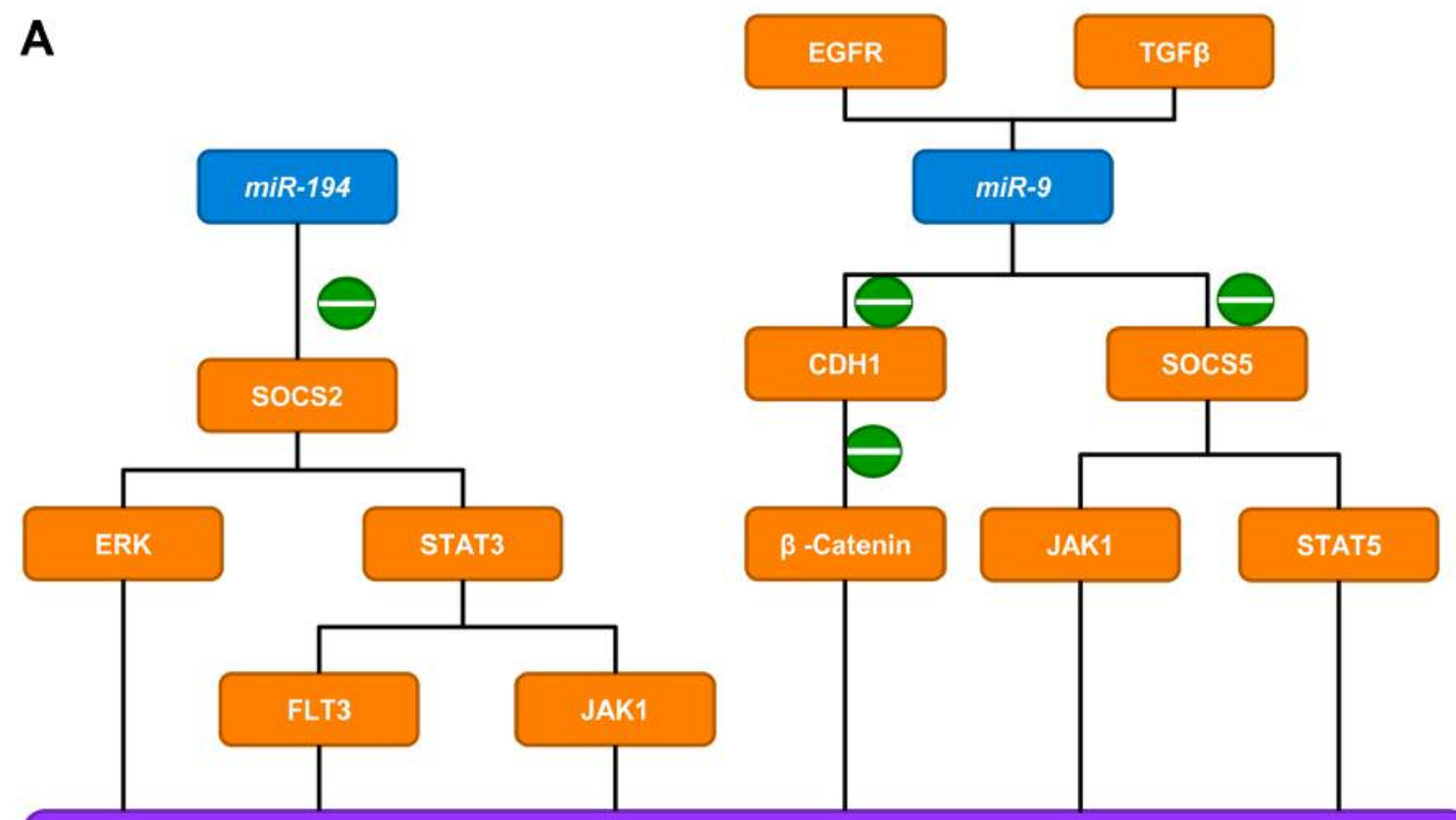

\section{Pro-invasive genes}
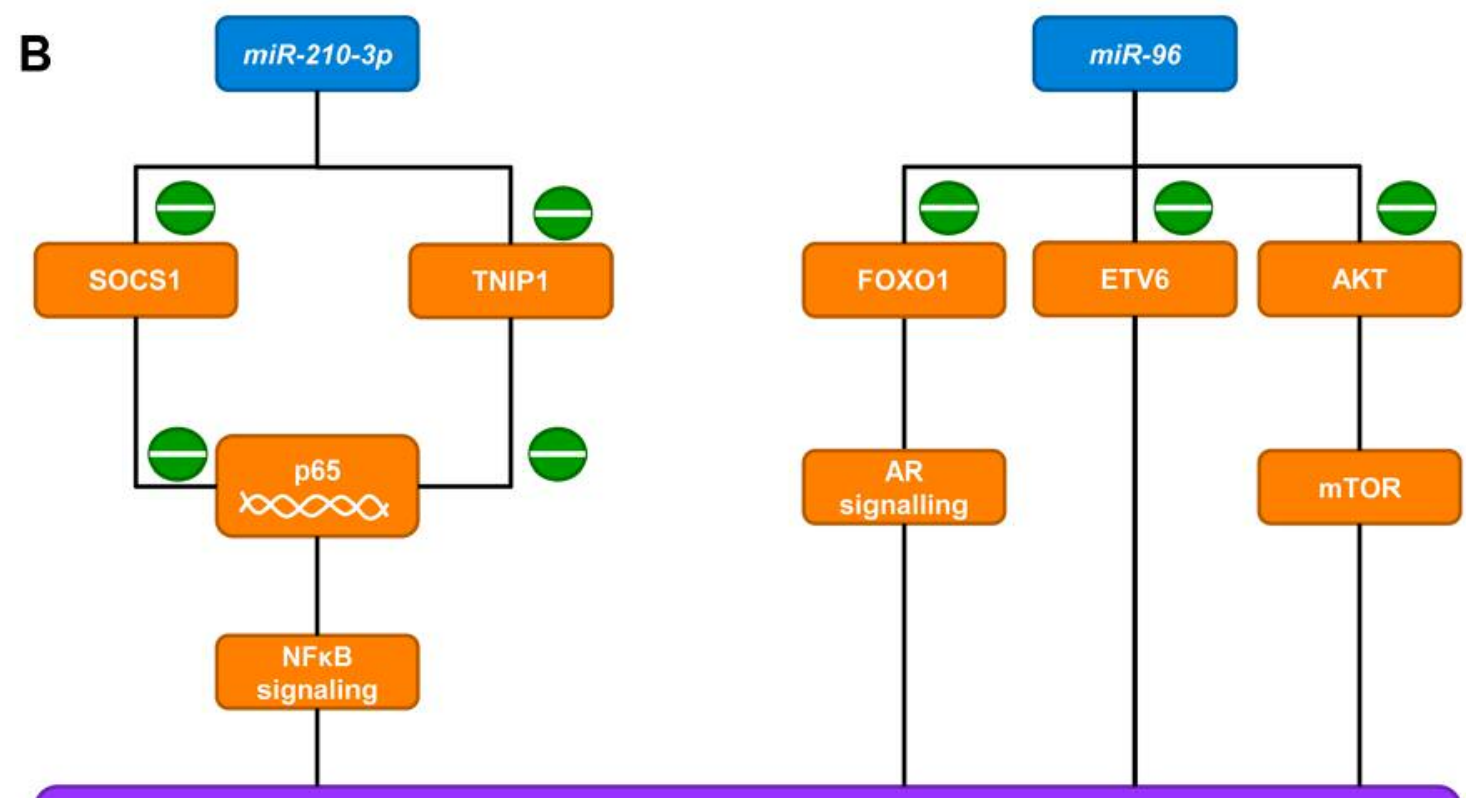

\section{Pro-invasive genes}

Figure 2. miRs up-regulated in metastatic prostate cancer: A: miR-194 and miR-9; B: miR-210-3p and miR-96. Suppressors of cytokine signaling (SOCS) 1, 2, 5 are direct targets of miR-210-3p, miR-194 and miR-96. Other direct targets are cadherin 1 (CDH1), TNF $\alpha$-induced protein 3-interacting protein (TNIP1), forkhead box 1 (FOXO1), ETS variant 6 (ETV6) and AKT8 viral oncogene cellular homolog (AKT). Inhibition of these targets by the corresponding miRs results in activation of pro-invasive genes. AR: Androgen receptor; EGFR: epidermal growth factor receptor; ERK: extracellular-regulated kinase; FLT3: FMS-like tyrosine kinase 3; JAK1: Janus kinase 1; mTOR: mechanistic target of rapamycin; NFKB: nuclear factor $k B$; p65: protein 65; STAT: signal transducer and activator of transcription factor; TGF $\beta$ : transforming growth factor $\beta$. 


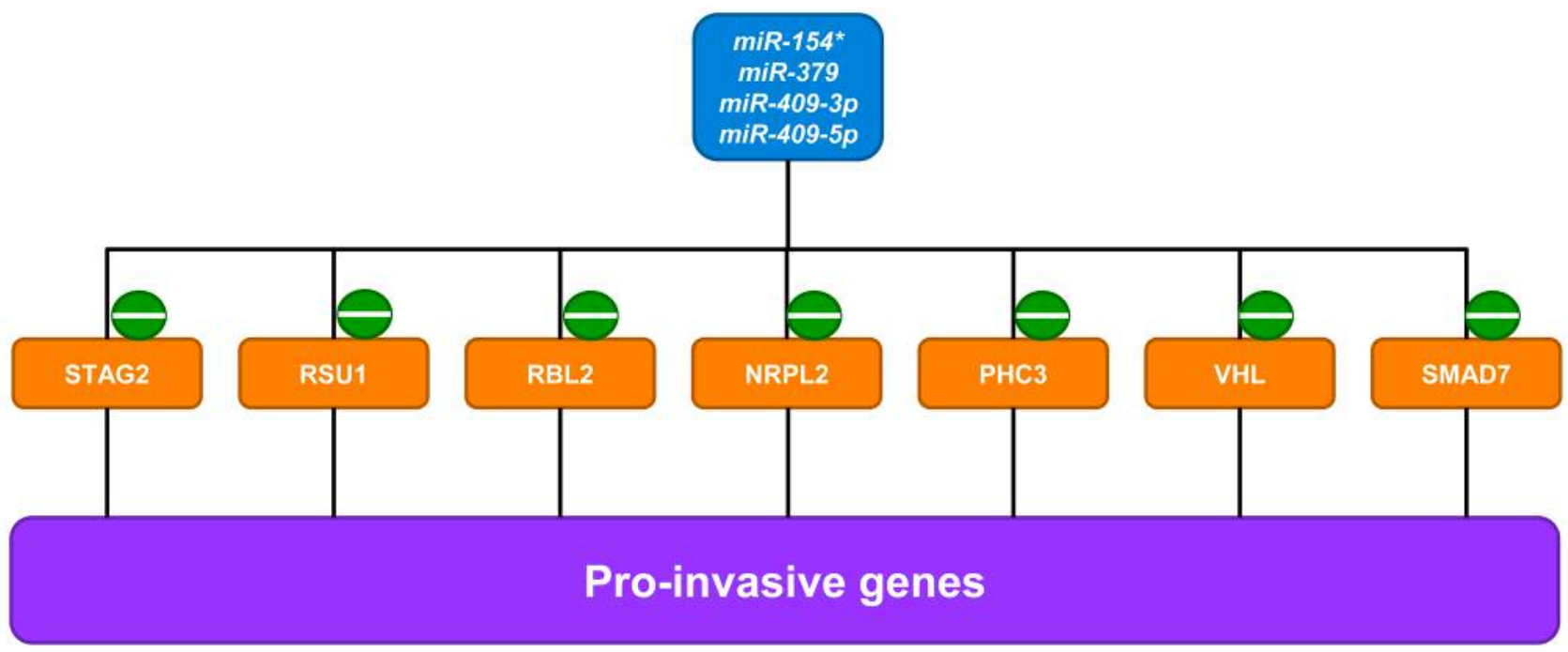

Figure 3. miR-154*, miR-379, miR-409-3p and miR-405-5p target tumor suppressor genes. These miRs are up-regulated in metastatic prostate cancer and inactivation of tumor suppressor-related mRNAs results in the activation of pro-invasive genes. NRPL2: Nitrogen permease regulatorlike 2; PHC3: polyhomeotic homolog 3; RBL2: retinoblastoma-like 2; RSU1: RAS suppressor protein 1; STAG2: stromal antigen 2, VHL: von Hippel Lindau gene.

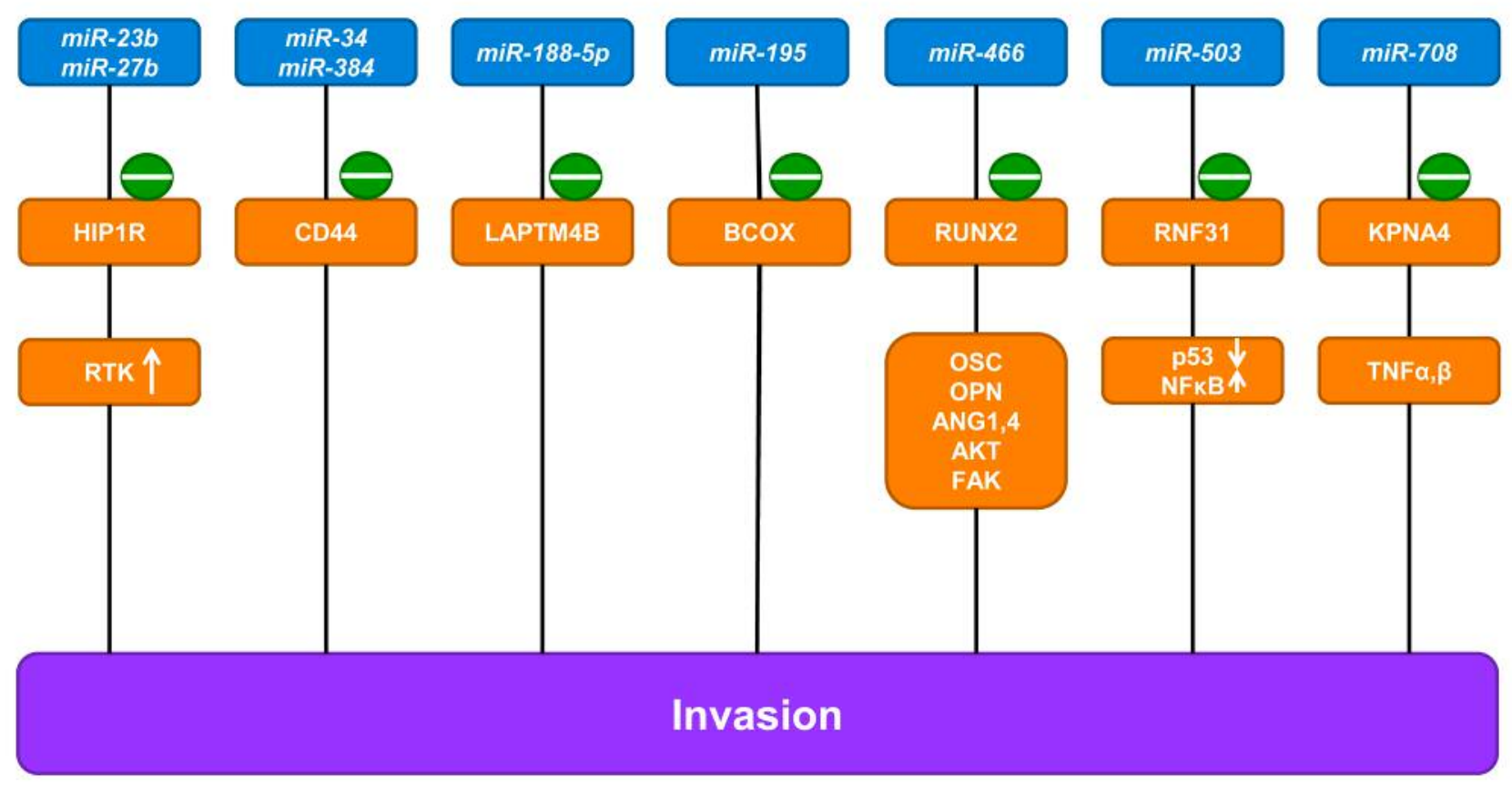

Figure 4. Overview of miRs down-regulated in metastatic prostate cancer targeting mRNAs exerting different functions. These miRs include miR23b, miR-27b, miR-34, miR-188-5p, miR-195, miR-384, miR-466,miR-503 and miR-708. AKT: AKT8 viral oncogene cellular homolog; ANG: angiopoietin; BCOX (KIAA0100): breast cancer overexpressed gene 1; CD44: cluster of differentiation 44; FAK: focal adhesion kinase; HIP1R: Huntington-interacting protein 1-related protein; KPNA4: karyopherin 4; LAPTM4B: lysosome transmembrane protein 4; NFkB: nuclear factor $B$; OPN: osteopontin; OSC: osteocalcin; p53: protein 53; RNF-31: ring finger protein 31; RTK: receptor tyrosine kinase; RUNX2: RUNT-related transcription factor; TNF: tumor necrosis factor. 

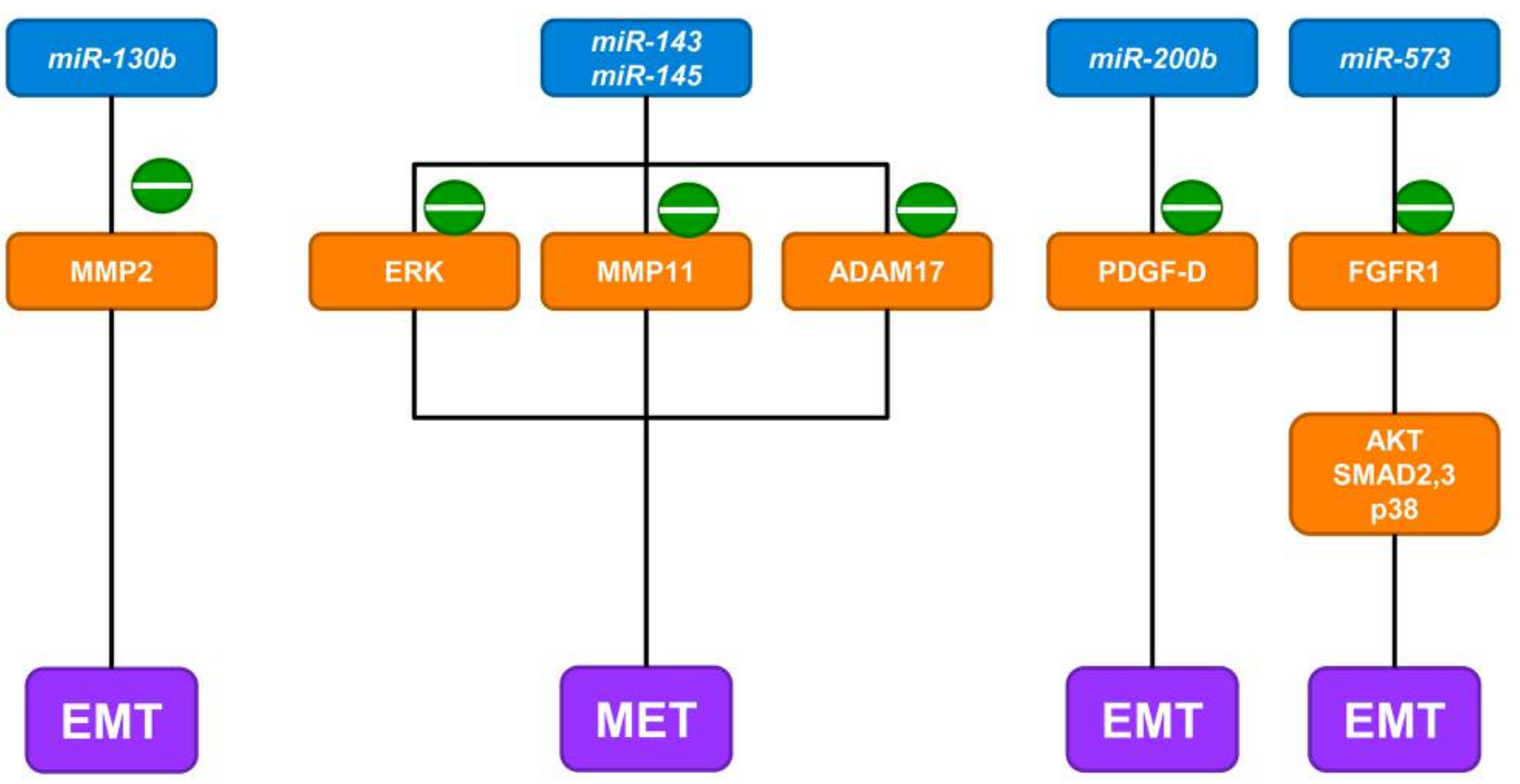

Figure 5. miR-130b, miR-143, miR-145, miR-200b and miR-573 mediate epithelial-mesenchymal transition or mesenchymal-epithelial transition. These miRs are down-regulated in metastatic prostate cancer and cause epithelial-mesenchymal transition (EMT) or mesenchymal-epithelial transition (MET). AKT: AKT8 viral oncogene cellular homolog; ADAM 17: a disintegrin and metalloproteinase 17; platelet-derived growth factor D; ERK: extracellularregulated kinase; FGFR1: fibroblast growth factor receptor-1; MMP: matrix metalloproteinase; p38: p38 mitogen-activated protein kinase.

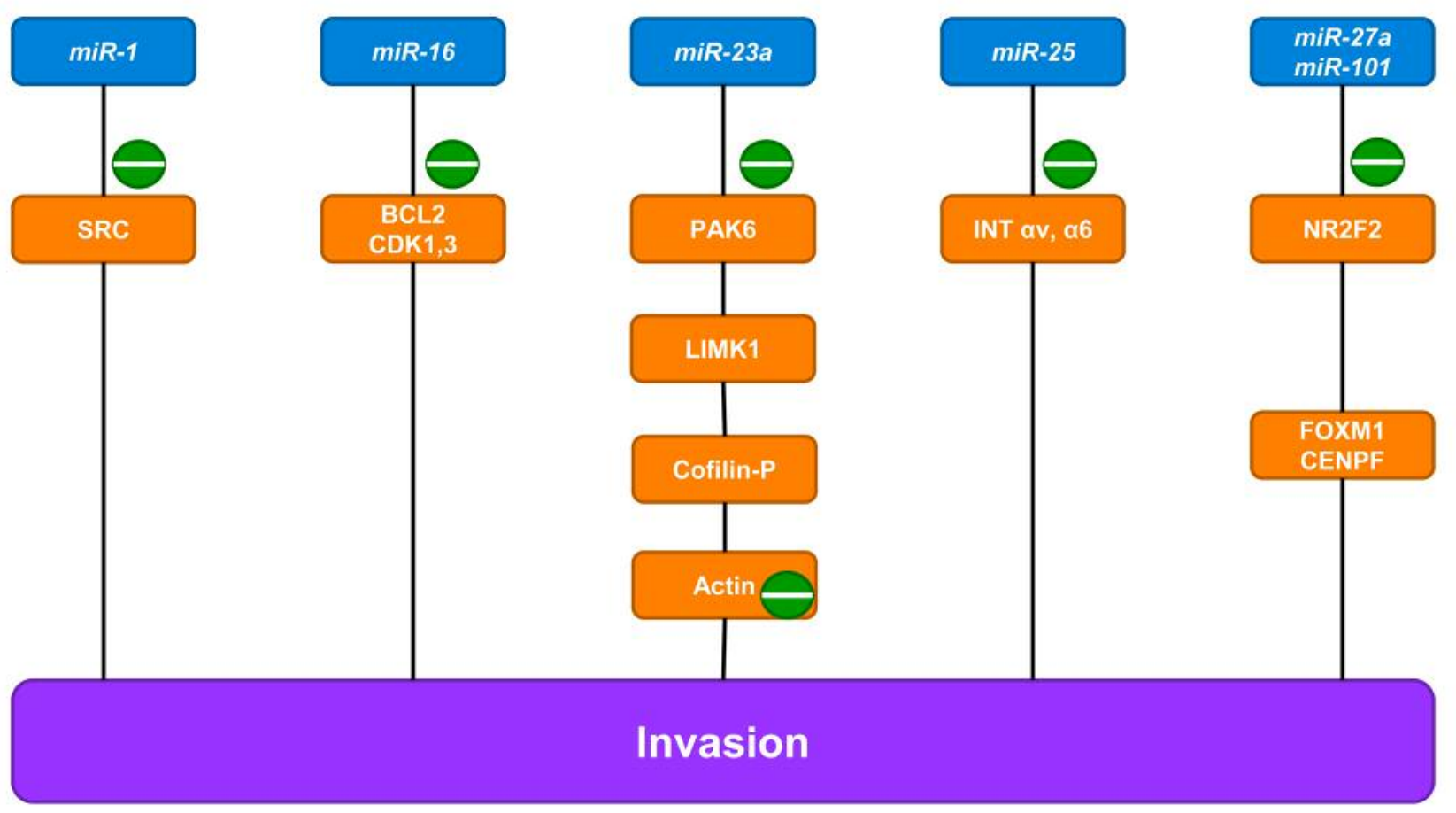

Figure 6. miR-1, miR-16, miR-23a, miR-25, miR-27a and miR-101 interfere with cellular signaling mechanisms. These miRs are down-regulated in metastatic prostate cancer and target mRNAs which promote invasion. BCL2: B-Cell lymphoma 2, CDK: cyclin-dependent kinase; CENPF: centromer protein $F$ precursor; Cofilin-P: phosphorylated cofilin; NR2F2: nuclear receptor subfamily 2, group F, member 2; FOXM1: forkhead box M1; INT: integrin; LIMK1: LIM kinase 1; PAK6: p21-activated kinase 6; SRC: tyrosine kinase SRC. 
Orthotopically engrafted PC CWR22Rv-1 cells gave rise to increased metastatic foci when co-implanted with immortalized pre-adipocytes. Mechanistically, the observed effects were due to the inhibition of AR by $m i R-301$ in tumor cells (70). AR has been identified as a negative regulator of TGF $\beta /$ SMAD/MMP9 signaling (71-75).

\section{miRs Inhibiting PC Metastasis}

$m i R-34 a$ and $m i R-383$ target $C D 44$. It has been shown that PC stem cells express CD44 and confer tumorigenic properties on these cells $(76,77)$. CD44 has been identified as a direct target of $m i R-34 a$ and $m i R-383$ in PC cells $(78,79)$ (Figure 4). In addition, $m i R-373$, $m i R-520 c$ and $m i R-708$ were shown to target CD44 and modulate in vitro-invasion of PC cells (80, 81). $m i R-34 a$ inhibited clonal and clonogenic properties of PC cells (78). Tail vein injection of $m i R-34 a$ into nude mice with orthotopic LAPC9 tumors inhibited lung metastasis and extended the survival of the animals without affecting tumor growth (78). Ectopic expression of $m i R-383$ suppressed the tumorigenicity of DU145, PC3 and LNCaP PC cell lines, while silencing of $m i R-383$ induced tumorigenicity of normal prostate epithelial cells (78). $m i R-383$ inhibited the capacity of $\mathrm{CD}_{4} 4^{+} \mathrm{PC}$ cells to initiate tumors, and its ectopic expression in PC3-3M cells tagged with luciferase suppressed growth of xenografts in vivo (78). Inoculation of these cells expressing $m i R-383$ ectopically into the left ventricles of nude mice reduced metastasis (78). Thus, CD44 is a crucial mediator of metastasis (82). Low expression of $m i R-383$ is associated with poor survival outcome in patients with $\mathrm{PC}$ and an inverse correlation of expression of $m i R-383$ in PC tissues and lymph node metastasis has been found (78).

miR-573 targets FGF receptor $R 1$ and attenuates EMT. miR573 is down-regulated in PC and its expression levels inversely correlate with survival (83). miR-573 is induced by transcription factor GATA-binding protein 3, a key factor in preventing PC progression through antagonizing AKT signaling (84). miR-573 suppressed migration and invasion of $\mathrm{VCaP}$ and PC3 PC cell lines (83). $\mathrm{VCaP}$ transfected with $m i R-573$ gave rise to significantly fewer lung metastases compared to control cells after implantation into the dorsal flank of immuno-deficient mice (83). FGFR1 was identified as a direct target of $m i R-573$ (83). FGFR1 is a mediator of EMT and an activator of downstream signaling pathways such as AKT, SMAD2, SMAD3 and p38 mitogen-activated protein kinase (85) (Figure $5)$. An inverse correlation between expression levels of $m i R-573$ and FGFR1 has been found in prostate tumors (83).

miR-143 and miR-145 induce mesenchymal-epithelial transition (MET). Down-regulation of $m i R-143$ and $m i R-145$ is associated with tumor progression and metastasis (86). $m i R$ 143 and $m i R-145$ were shown to induce transdifferentiation of mesenchymal cells towards epithelial cells (86). As shown with miR-transfected PC3 cells, both $m i R-143$ and $m i R-145$ inhibited growth of tibial injected cells and reduce the size of skeletal lesions (1). miR-143 can interfere with extracellular signal-regulated kinase (ERK) signaling, which is involved in the MET pathway $(87,88)$, and $m i R-145$ has been shown to target MMP11, and a disintegrin and metalloproteinase 17 (ADAM17) (89) (Figure 5). miR-143 is down-regulated in prostate tumors when compared with matching normal prostate tissues (Figure 1).

miR-200b attenuates EMT. miR-200 was up-regulated by AR and reversed EMT in PC3 cells (90). miR-200 induced an increase in expression of differentiation markers of prostate epithelium such as cytokeratins CK8 and CK18, suppressed mesenchymal features such as zinc finger and homeobox transcription factor1 (ZEB1) and reduced invasion of PC3 cells in vitro (90). Transfection of PC3 cells with miR-200b suppressed growth and angiogenesis of PC3 xenografts (90). Orthotopic injection of these cells dramatically reduced spontaneous metastasis as assessed by monitoring fluoresence. miR-200b also inhibited platelet-derived growth factor-D in PC3 cells (91) (Figure 5). From a mechanistic point of view, the direct targets of $m i R-200 b$ need to be identified in further detail.

miR-130b targets MMP2. $m i R-130 b$ is down-regulated in clinical PC specimens (92). Stable expression of $m i R-130 b$ in M12 PC cells suppressed migration and invasion in wound-healing assays without affecting proliferation. Intracardiac injection of luciferase-tagged PC3 cells reduced tissue metastasis, as detected by bioluminescence. MMP2 was identified as a direct target of $m i R-130 b(92)$ and acts as a promoter of metastasis through degradation of the extracellular matrix (93) (Figure 5).

miR-449a targets prostate leucine zipper gene (PrLZ). Downregulation of $m i R-449$ is related to PC clinical stage and distant metastasis (94). $m i R-449 a$ suppressed proliferation, promoted apoptosis and restricted invasion and tube formation by LNCaP and PC3 cells (94). miR-449 suppressed tumor formation of subcutaneously implanted transfected PC3 cells and reduced the number of animals with tumor metastases (94). PrLZ has been identified as a direct target of $m i R-449$. PrLZ is a member of the tumor protein D52 (TPD52) family, which is specifically expressed in prostate tumors and is associated with progression of PC (95-97).

\section{miRs Interfering with Signaling}

miR-25 targets integrin components. miR-25 was downregulated in aldehyde dehydrogenase (ALDH)-positive normal and transformed PC stem cells and steadily increased upon luminal differentiation (98). ALDH is a functional marker of 
CSCs and progenitors (99). $m i R-25$ overexpression reduced integrin $\alpha \mathrm{v}$ and integrin $\alpha 6$ in human PC cell lines and PC stem cells (98) (Figure 6). Integrins $\alpha v$ and $\alpha 6$ have been identified as pro-invasive integrins $(100,101)$. In PC stem cells, $m i R-25$ affected morphology and reduced migration, switching them to a less invasive phenotype due to cytoskeletal reorganization (98). The impact of $m i R-25$ on metastasis was monitored by injecting fluorescently labeled $m i R-25$ expressing PC3 cells into the circulatory system of embryonic zebrafish $(98,102)$. It was found that $m i R-25$ disrupted extravasation and colonization of distant sites in vivo (98).

miR-1 targets $v$-src sarcoma viral oncogene homolog (SRC). $m i R-1$ is reduced in PC compared with benign tissue and its expression further decreases with metastatic progression (103-105). miR-1 was induced by AR and inhibits in vitro proliferation and in vivo growth of RASB 1 cells, a cell line derived from experimental bone metastases of DU145 PC cells expressing mutated RAS V12G37 $(103,106)$. SRC was identified as a direct target of $m i R-1$ (103) (Figure 6). Bone and brain metastases of RASB 1 cells transfected with $m i R-1$ were evaluated after intracardiac inoculation. Developing metastases were delayed in time from 3 weeks to 10 weeks, diminished in size and mainly found in the brain. Expression of SRC in miR-1-expressing RASB1 cells restored metastatic ability. Furthermore, it was shown that EGFR promotes PC bone metastases by down-regulating $m i R-1$ and activating the transcription factor TWIST1 (107). In this context, translocation of EGFR into nuclei and increased nuclear EGFR as well as reduced $m i R-1$ expression correlate with worse clinical outcome (107).

miR-16 targets BCL2 and cell-cycle-related genes. miR-16 was identified in a functional screen for miRs which inhibit proliferation of 22Rv1 PC cells (108). Expression of miR-16 was low in the majority of PC clinical samples in comparison to matching normal tissues. miR-16 can induce apoptosis of PC cells by targeting BCL 2 by inhibiting the translation of its mRNA (20) (Figure 6). Transfection of PC with $m i R-16$ down-regulated the expression of several cell cycle-related genes such as cyclin D3 as well as cyclindependent kinases 1 and 3 (108). In vivo bone metastasis of luciferase-tagged PC3 cells ectopically expressing $m i R-16$ cells was inhibited after intracardiac injection. A $m i R-16$ mimetic complexed to atelocollagen administered i.v. into mice inhibited metastasis into the thorax, jaws and legs, suggesting that systemic delivery of $m i R-16$ could be a novel strategy to inhibit prostate tumor growth in the bones (108).

miR-23a targets p21-activated kinase 6 (PAK6). miR-23a is reduced in PC cell lines and tissues in comparison to controls and low expression is associated with aggressive and poor prognostic PC phenotype (109). miR-23a suppressed invasion and migration of PC3, DU-145 and C4-2B PC cell lines in vitro (109). Intraprostatic injection of luciferase-tagged PC3 cells, transfected with $m i R-23 a$ gave rise to fewer metastatic lesions as revealed by bioluminescence (109). $m i R-23 a$ was found to dissolute stress fibers, suppress the formation of actin fibers (109) and inhibit PC cell motility $(110,111)$. PAK6 was identified as a direct target of $m i R-23 a$ (109) (Figure 6). PAK6 directly phosphorylates LIM kinase 1 (112) and the latter phosphorylates cofilin $(113,114)$, suppressing stress fibers and actin filaments required for cell motility and invasion (110-112).

miR-27b and miR101 target nuclear receptor subfamily 2 group F member 2 (NR2F2) (previously COUP-TFII). miRs$27 b$ and $m i R-101$ directly target NR2F2, a master regulator of the metastatic gene regulatory network and member of the orphan nuclear receptor family, by modulating the expression of transcription factors ZEB1 and ZEB2 $(115,116)$ (Figure $6)$. Loss of $m i R-101$ correlated with increase in the NR2F2forkhead box M1 (FOXM1)-centromer protein F precursor (CENPF) signaling activity in clinical data sets (115). FOXM1 is a transcription factor which is overexpressed in $\mathrm{PC}$ and contributes to proliferation, angiogenesis and metastasis (117). CENPF is a structural component of the kinetochore and a known target of FOXM1 (118). Both FOXM1 and CENPF levels are increased in metastatic PC (48). In vivo, lymphatic metastasis was promoted in LNCaP cells in which $m i R-101$ and $m i R-27 b$ were inhibited after injection into mouse prostate (115). Clinical data revealed that loss of function of $m i R-101$ and $m i R-27 b$ leads to overexpression of NR2F2, FOXM1 and CENPF, and enhancement of metastasis and drug resistance (115).

\section{miRs Targeting Bone-related Targets}

miR-466 targets Runt-related transcription factor 2 (RUNX2). $m i R-466$ was underexpressed in PC compared to normal tissues and inhibited invasion and migration of PC3 and DU145 PC cells (119). In vivo, PC3 cells constitutively expressing $m i R-145$ exhibited reduced growth of the primary tumor after orthotopic implantation into the posterior prostatic lobe of athymic mice (119). Intracardiac injection of these cells suppressed spontaneous metastases compared to controls. miR-466 directly targets bone-related transcription factor RUNX2, which is involved in expression of several genes related to tumor growth and metastasis, such as osteopontin, osteocalcin, angiopoietins 1 and 4, MMP11, vimentin, focal adhesion kinase (FAK) and AKT $(120,121)$ (Figure 4).

\section{Other miR-related Targets}

miR-23b and miR-27b target Huntington-interacting protein 1related protein $(H I P 1 R)$. $m i R-23 b$ and $m i R-27 b$ are encoded by the miR cluster $23 \mathrm{~b} / 27 \mathrm{~b}$ and are down-regulated in CRPC 
(122). Ectopic expression of $m i R-23 b,-27 b$ in CRPC cell lines ALV31 and PC3 ML reduced mobility and invasion, increased E-cadherin and reduced expression of Ras-related C3 botulinum toxin substrate 1 (RAC1), even though the proliferation rate was not altered $(122,123)$. In vivo, orthotopic xenografts of aggressive PC cells transduced with $m i R-23 b$ and $m i R-27 b$ were not affected with respect to growth of the primary tumor, however, distant metastases were significantly reduced (123). $m i R-23 b$ and $m i R-27 b$ down-regulated HIP1R, a component of clathrin-coated pits and vesicles that may link the endocytic pathway to the actin cytoskeleton $(123,124)$ (Figure 4). HIP1R binds 3-phosphoinosites and may promote survival by stabilizing receptor tyrosine kinases following ligand-induced endocytosis (124).

miR-188-5p targets lysosome transmembrane protein 4 (LAPTM4B). Down-regulation of $m i R-188-5 \mathrm{p}$ is associated with metastasis and poor prognosis in PC (125). miR-188$5 \mathrm{p}$ inhibited proliferation, invasion and migration of PC3 and LNCaP PC cell lines in vitro (125). Ectopic expression of $m i R-188-5 \mathrm{p}$ inhibited tumor growth and metastasis of PC3 cells implanted into the dorsal flank of nude mice (125). LAPTM4B has been identified as a direct target of miR-188-5p in PC3 and LNCaP cells (125) (Figure 4). LAPTM4B is located in late endosomes and lysosomes and can promote proliferation, invasion and inhibit apoptosis and is able to initiate autophagy (126). LAPTM4B is associated with poor prognosis and metastasis in several types of tumors (127-130).

miR-195 targets breast cancer overexpressed gene 1 (KIAA0100, previously BCOX1). PC patients with low miR195 expression were found to have a poorer prognosis (131). Restoring miR-195 expression in PC3 and LNCaP cells inhibited proliferation, migration and invasion (131). miR-195 down-regulates BCOX1 (Figure 4, which is associated with the recurrence and progression of triplenegative breast cancer $(132,133)$. BCOX1 is significantly overexpressed in patients with PC and lymph node metastasis and is associated with PC progression (131). miR-195 reduced growth and metastasis of PC3 and LNCaP cells implanted into the dorsal flanks of immunodeficient mice (131).

miR-503 targets ring finger protein 31 (RNF31). miR-503 inhibits proliferation, migration and invasion of PC3 and LNCaP cells in vitro (134) and targets RNF31, also known as HOIL-1 interacting protein $(135,136)$ (Figure 4). RNF31 catalyzes the formation of linear peptide bonds between the amino terminus of methionine and the carboxy-terminal glycine (137). RNF31 promotes degradation of p53 (138) and facilitates NFKB signaling (139). RNF31 knockdown in PC3 cells attenuated metastasis of these cells implanted subcutaneously into the dorsal flanks of nude mice (134). RNF31-positive staining is associated with PC progression and unfavorable outcome (134).

miR-708 targets karyopherin. miR-708 targets karyopherin (KPNA4) (Figure 4). The expression levels of karyopherin correlate with $\mathrm{PC}$ progression. $m i R-708$ inhibited migration of PC3 cells. KPNA4 knockdown attenuated primary tumor invasion of PC3 xenografts as well as bone metastasis (140). Central mediators of karyopherin function are $\mathrm{TNF} \alpha$ and TNF $\beta$, which enhance PC cell migration, stimulate osteoclasts and bone resorption $(141,142)$ and can alter macrophage polarization towards the M2 subtype in the tumor microenvironment (143).

\section{miRs with a Multitude of Identified Targets}

miR-141 targets CD44, methyltransferase EZH2 and several Rho-GTPases. miR-141 is a member of the miR-200 family and is underexpressed in PC stem/progenitor populations in xenografts and tumors (144). Forced expression of $m i R-141$ in $\mathrm{CD} 44^{+}$and bulk PC cells suppressed tumor regeneration and invasion and enforced an epithelial phenotype with loss of the mesenchymal phenotype (144). miR-141 inhibited invasion in PC3, DU145, VCaP, LAPC4, LNCaP and C4-2 PC cells. Ectopic expression of $m i R-141$ in CD44 ${ }^{\text {high }}$ PC3 and DU-145 PC cells and implantation into the dorsal prostate of non-obese diabetic/severe combined immunodeficient mice resulted in smaller primary tumors and fewer lung metastases. Doxycycline-inducible expression of $m i R-141$ in LAPC9 xenografts reduced growth of xenografts and diminished metastasis (144). The mechanism of action of $m i R-141$ is based on inhibition of CSC-related molecules, cytoskeleton- and cell-cycle-related components, resulting in inhibition of tumor growth and metastasis. CSC-related targets such as CD44 and histone methyltransferase $\mathrm{EZH} 2$, a component of the polycomb repressive complex 2 , both involved in CSC maintenance, invasion and metastasis, are direct targets of $m i R-141$ (144, $145)$. In addition, several invasion- and motility-modulating Rho GTPases, such as cell division cycle 42 (CDC42), rasrelated $\mathrm{C} 3$ botulinum toxin substrate 1 (RAC) and actinrelated protein $2 / 3$ complex subunit 5 (ARPC5) have been identified as direct targets of $m i R-141$ (Figure 7). These targets are involved in formation of actin stress fibers and lamellipodia, and cytoskeletal reorganization (146-148). Furthermore, $m i R$ - 141 inhibited cell-cycle-related molecules such as CDK4 and CDK6. However, it is not yet clear, whether these are direct targets of $m i R-141$.

miR-141-3p targets TNF receptor-associated factors (TRAF) 5 and 6. $m i R-141-3 p$ is an inhibitor of bone metastasis of PC cells and is down-regulated in bone-metastatic PC tissues 


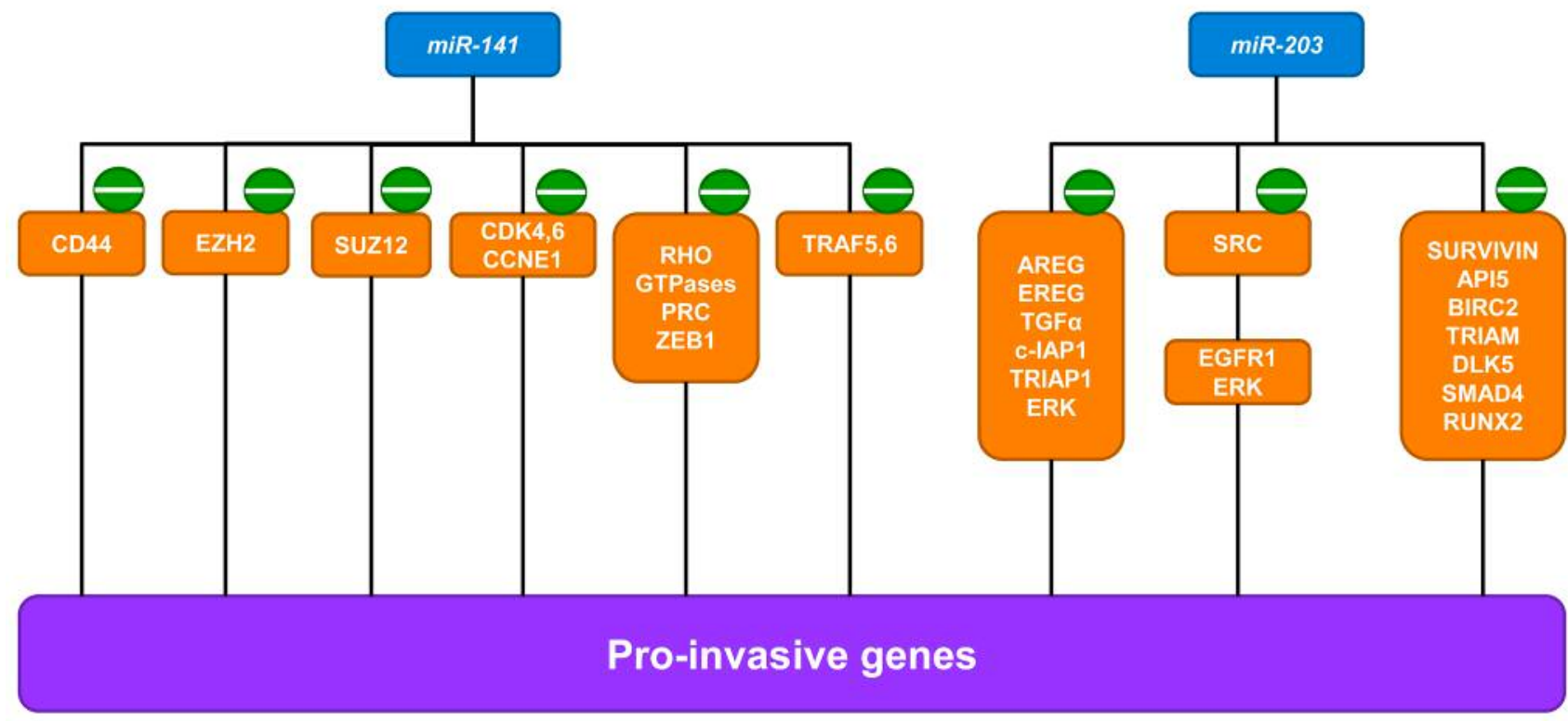

Figure 7. miRs down-regulated in metastatic prostate cancer and targeting several mRNAs simultaneously. The mechanism of action of miR-141 and miR-203 are outlined. API5: Apoptosis-inhibitor protein 5; AREG: amphiregulin; cIAP1: cellular inhibitor of apoptosis 1; CCNE1: cyclin E; CD44: cluster of differentiation 44; CDK: cyclin-dependent kinase; DLX5: distal-less homeobox 5; EGFR: epidermal growth factor receptor; EREG: epiregulin; ERK: extracellular-regulated kinase; EZH2: histone methyltransferase EZH2; PRC: polycomb repressor complex; RHO GTPases: RHO guanosine triphosphatase; RAP1: small GTPase RAP1; RUNX2: Runt-related transcription factor 2; SMAD4: transcription factor SMAD4; SRC: tyrosine kinase SRC; SUZ12: core protein of EZH2; TGF : transforming growth factor $\alpha$; TRAF: TNF receptor-associated factor; TRIAP1: TP53regulated inhibitor of apoptosis 1; ZEB1: zinc finger E-box binding homeobox 1 .

(149). Intracardiac injection of PC3 cells overexpressing $m i R-141-3 p$ reduced metastasis to the bones in comparison to controls with fewer metastatic nodules and smaller osteolytic areas of metastatic tumors (149). TRAF5 and TRAF6 were identified as direct targets of $m i R-141-3 \mathrm{p}$ (149). TRAF5 and TRAF6 modulate TNF-induced activation of NFKB signaling through binding to TNF receptor cytoplasmic domains (150) (Figure 7).

miR-203 inhibits EGFR signaling and anti-apoptotic proteins. $m i R-203$ levels are reduced during progression of PC. Ectopic expression of $m i R-203$ inhibited proliferation, invasion, migration and adhesion of PC cell lines such as DU145, RASB1 and PC3 (151-153). miR-203 induced MET in PC cells with concomitant expression of E-cadherin (153). RASB 1 cells ectopically expressing $m i R-203$ exhibited a significant decrease in brain and bone metastases after intracardiac injection (151). In a second in vivo model, $m i R$ 203 was shown to inhibit growth of DU-145 cells after subcutaneous injection (152). Several miR-203-related targets have been identified, depending on the system under investigation. The first system is based on DU145/RASB1 bone metastasis-derived clones whose parental cell line was transformed with RAS G37 (151). In these cell lines, the mechanism of action of $m i R-203$ is based on activation of EGFR signaling as well as inhibition of anti-apoptotic proteins (151). EGFR ligands amphiregulin (AREG), epiregulin (EREG) and transforming growth factor $\alpha$ (TGF $\alpha$ ) as well as apoptosis-inhibiting proteins apoptosis inhibitor 5 (API5), cellular inhibitor of apoptosis protein (c-IAP1) (BIRC2) and p53-regulated inhibitor of apoptosis 1 (TRIAP1) have been identified as targets of $m i R-203$, which result in activation of metastasis-promoting SRC and ERK signaling (151). In a second system, RAP1, a member of the RAS family of GTPases which are involved in cell-cell and cell-extracellular matrix interactions $(154,155)$ was identified as a direct target of miR-203 in DU145 cells (152). In a third system using PC3 cells, survivin, ZEB2, RUNX2, distal-less homeobox 5 (DLX5) and SMAD4 were identified as direct targets of $m i R-203$ (156-158). In PC3 cells, $m i R$ 203 reduced expression of osteopontin and osteocalcin genes, which are key osteoblastic genes, indicating that $m i R$ 203 may regulate the osteomimetic properties of PC cells (152). In LNCaP cells, miR-203 was identified as a suppressor of LIM and SH3 protein 1 (LASP1), which impaired proliferation and migration of PC cells (159-161). The mechanism of action of miR-203 is summarized in Figure 7. 


\section{Therapeutic Aspects}

We have summarized PC-metastasis related miRs based on preclinical validation by in vitro and in vivo systems, as well as clinical correlations. Some of them are up-regulated in PC tissues in comparison to corresponding normal tissues, but the majority are down-regulated in PC tissues. Reconstitution or inhibition of their functions are potential therapeutic options. Therapeutic strategies and current pitfalls are summarized in several excellent reviews (162-167) and therefore these issues are not discussed in detail in this review.

Options for reconstitution are ectopic expression by expression vectors for the corresponding miRs, doublestranded synthetic RNAs that mimic endogenous miRs (165), or non-specific induction of corresponding miRs with small molecules (165). To inhibit the functionality of miRs, short nucleotides with chemically enhanced stabilities and nuclease resistance are administered. Types of miRinterfering drugs include antisense oligonucleotides and single-strand DNA-like molecules such as locked nucleic acids. In the same way, small double-stranded interfering RNAs (siRNA) and antagomirs, which are RNAs of 23 nucleotides modified with cholesterol at the 3'-end, ultimately lead to RNA silencing by RNA interference. miR sponges, another approach to inhibiting unwanted actions of miRs, contain multiple binding sites for a miR of interest, thus interfering with their functionality (163-167). Considerable progress has been achieved by optimizing the pharmacokinetic/pharmacodynamic properties of these agents by chemical modification significantly improving the binding affinity, stability and target modulation (164-167).

Issues which have to be addressed are: hybridizationassociated off-target effects, hepatotoxicity, design of efficient delivery systems, rapid clearance by the reticuloendothelial system, and enhancement of circulation time when injected into the bloodstream (165-167).

By increasing the molecular weight of RNAs through conjugation to polyethylene glycol a fast renal clearance can be circumvented. The serum half-life can be further prolonged by coupling of the interfering nucleotides to albumins or cholesterol which bind to circulating lipoproteins, thus shielding the nucleotides from renal clearance (168-170). Apart from this, complexing the nucleotides with nanoparticles also reduces the risk of sideeffects, e.g. immunogenicity and cytokine release syndrome, while the increased molecular weight is expanding the retention time (171).

Efficient delivery systems are currently being explored to allow hydrophilic RNAs to cross the cell membrane and to minimize off-target effects. To facilitate the entry of nucleotides into the endosomes, lipophilic polymers such as lipid nanoparticles, dynamic polyconjugates or oligonucleotide nanoparticles, which mask hydrophilic RNAs, are used (172179). Targeting ligands, aptamers and antibodies coupled to nucleotides not only shield miR-interfering drugs from fast renal clearance, but also allow targeting of specific cell types. Thus, hapten-binding bi-specific antibodies were shown to facilitate the knockdown of the target gene by delivering haptenylated siRNA complexed with dynamic polyconjugates (180-190). Upon internalization, release of RNA can be facilitated by conjugates coupled via acid-sensitive or protease cleavable linkers within the acidic endosome (191, 192). Furthermore, complexation with cell-penetrating viral proteins, e.g. trans-activating transcriptional activator-derived protein from human immunodeficiency virus 1 , Drosophila-derived penetratin or chimeric peptides overcome the endosomal barrier and accomplish endosomal escape (193-195). However, potential toxicity and immunogenicity favor the use of humanderived cell-penetrating peptides such as neurturin as they display reduced toxicity and enable the passage of nucleotides through the endosomal membrane to the cytosol (195-197). In this way, cell-specific delivery packages can be assembled by formulating nucleotides with lipophilic polymers and targeting entities for delivery of RNAs (180-184, 186).

As a corollary of the many different factors that influence the delivery of nucleotides, such as tissue-specific targeting, cell penetration and endosomal escape, further studies especially in in vivo mouse models - should explore and address the current delivery bottleneck to resolve the limitations of the delivery system.

The extent of delivery of these agents to target cells for achieving therapeutic effects is probably dependent on the specific system under consideration and might be affected by induction of immune responses against released tumor antigens, resulting in death of tumor cells which do not express the therapeutic target.

The miRs discussed in this review were validated in different preclinical metastasis-related models such as experimental metastasis (tail vein injection and lung metastasis), spontaneous metastasis after subcutaneous implantation, metastasis after intracardiac or orthotopic intraprostatic injection, or delivery of tumor cells into the bone. Albeit targets have been identified for the described miRs, in many cases, the precise steps of their interaction in the metastatic cascade remain to be identified. The interpretation of the therapeutic relevance of specific miRs is complicated by the fact that in vivo data are restricted to very specific systems and evaluation of in vivo data simultaneously covering several metastasis-related models are not available.

What should be the profile of a PC-related anti-metastatic miR-related therapeutic agent? Besides inhibiting the migration and invasion, one of the requirements should be an ablative effect on circulating and disseminated tumor cells such as inhibition of proliferation and induction of apoptosis. 
If the agent under consideration does not match these features, increased cytotoxicty of an agent used in combination studies or reversal of therapy resistance would be an additional useful therapeutic feature. Interference with growth of established PC-related metastases is another important feature for the selection of miR-related agents as therapeutic agents. Unfortunately, anti-metastatic miR-related agents have not yet been evaluated in settings with PCrelated metastatic burden.

Future experiments will show whether the pitfalls, as outlined, can be tackled successfully.

\section{Conflicts of Interest}

The Authors are (AE, FB, UB) or were (UHW) employed by Roche. Roche is interested in targeted therapies.

\section{References}

1 American Cancer Society: Facts \& Figures 2017, American Cancer Society, 2017, Atlanta.

2 Yap TA, Smith AD, Ferraldeschi R, Al-Lazkani B, Workman P and de Bono JS: Drug discovery in advanced prostate cancer: translating biology into therapy. Nature Drug Discov 15: 699718,2016

3 Yoo S, Choi SY, You D and Kim CS: New drugs in prostate cancer. Prostate Int 4: 37-42, 2016.

4 Spratt DE, Zumsteg ZS, Feng FY and Tomlins SA: Translational and clinical implications of the genetic landscape of prostate cancer. Nat Rev Clin Oncol 13: 597-610, 2016.

5 Flavin R, Pettersson A, Hendrickson WA, Fiorentino M, Finn S, Kunz L, Judson GL, Lis R, Bailey D, Fiore C, Nuttall E, Martin NE, Stack E, Penney KL, Rider JR, Sinnott J, Sweeney C, Sesso HD, Fall K, Giovannucci E, Kantoff P, Stampfer M, Loda $M$ and Mucci LA: SPINK1 protein expression and prostate cancer expression. Clin Cancer Res 20: 4904-4911, 2014.

6 Wilson MR and Zoubeidi A: Clusterin as a therapeutic target. Exp Opin Ther Targets 21: 201-213, 2017.

7 Higano CS: Potential use of custirsen to treat prostate cancer. Onco Targets Ther 6: 785-797, 2013.

8 Manca P, Patano F, Juliani M, Ribelli G, De Lisi D, Danesi R, Del Re M, Vincenzi B, Tonini G and Santini D: Determinants of bone metastasis in prostate cancer. Crit Rev Oncol 112: 5966, 2017.

9 Mundy GR: Metastasis to bone: Causes, consequences and therapeutic opportunities. Nat Rev Cancer 2: 584-593, 2002.

10 Loberg RD, Logothetis CJ, Keller ET and Pienta KJ: Pathogenesis and treatment of prostate cancer bone metastasis: Targeting the lethal phenotype. J Clin Oncol 23: 8232-8241, 2005.

11 Dushyanthen S, Cossigny DA and Quan GM: The osteoblastic and osteoclastic interactions in spinal metastases secondary to prostate cancer. Cancer Growth Metastasis 6: 61-80, 2013.

12 Obenauf AC and Massague J: Surviving at a distance: Organspecific metastasis. Trends Cancer 1: 76-91, 2015.

13 Conley-LaComb MK, Semaan L, Singarereddy R, Li Y, Heath EI, Kim S, Cher ML and Chinni SR: Pharmacological targeting of CXCL12/CXCR4 signaling in prostate cancer metastasis. Mol Cancer 15: 68, 2016.

14 Jung Y, Kim JK, Shiozawa Y, Wang J, Mishra A, Joseph J, Berry JE, McGee S, Lee E, Sun H, Wang J, Jin T, Zhang H, Dai J, Krebsbach PH, Keller ET, Pienta KJ and Taichman RS: Recruitment of mesenchymal stem cells into prostate tumors promotes metastasis. Nat Comm 4: 1795, 2013.

15 Luo J, Beer TM and Graff JN: Treatment of nonmetastatic castration-resistant prostate cancer. Oncology 30: 336-344, 2016.

16 Pillai RS: MicroRNA function: Multiple mechanisms for a tiny RNA? RNA 11: 1753-1761, 2005.

17 Croce CM: Causes and consequences of microRNA dysregulation in cancer. Nat Rev Genet 10: 704-714, 2009.

18 Lin S and Gregory RI: MicroRNA biogenesis pathways in cancer. Nat Rev Cancer 15: 321-333, 2015.

19 Peter ME: Targeting of mRNAs by multiple miRNAs: The next step. Oncogene 29: 2161-2164, 2010.

20 Cimmino A, Calin GA, Fabbri M, Iorio MV, Ferracin M, Shimizu M, Wojcik SE, Ageilan RI, Zupo S, Dono M, Rassenti L, Alder H, Volinia S, Liu CG, Kipps TJ, Negrini M and Croce CM: $m i R-15$ and $m i R-16$ induce apoptosis by targeting BCL2. Proc Natl Acad Sci USA 102: 13944-13949, 2006.

21 Svoronos AA, Engelman DM and Slack FJ: OncomiR or tumor suppressor? The duplicity of microRNAs in cancer. Cancer Res 76: 3666-3670, 2016.

22 Taylor MA, Sossey-Alaoui K, Thompson CL, Danielpour D and Schiemann WP: TGF- $\beta$ up-regulates $m i R-181$ expression to promote breast cancer metastasis. J Clin Inv 123: 150-163, 2013.

23 Weidle UH, Dickopf S, Hintermair C, Kollmorgen G, Birzele $\mathrm{F}$ and Brinkmann U: The role of micrRNAs in breast cancer metastasis: Preclinical validation and potential therapeutic targets. Cancer Genomics Proeomics 15: 17-39, 2018.

24 Weidle UH, Birzele F, Kollmorgen G and Nopora A: Potential micro-RNA-related targets for therapeutic intervention with ovarian cancer metastasis. Cancer Genomics Proteomics 15: 115,2018

25 Stiegelbauer V, Vychtilova, Falte, Karbiener M, Pehsert AM, Reichner A, Resel M, Heitzer E, Ivan C, Bullock M, Ling H, Deutsch A, Wulf-Goldenberg, Adiprasito JB, Stoeger H, Haybaeck J, Svoboda M, Stotz M, Hoefler G, Slaby O, Calin GA, Gerger A and Pichler M: miR-196b-5p regulates colorectal cancer cell migration and metastases through interaction with HOXB7 and GALNT5. Clin Cancer Res 23: 5255-5266, 2017.

26 Chang RM, Xiao S, Lei X, Yang H, Fang F and Yang LY: miRNA-478a promotes proliferation and metastasis in hepatocellular carcinoma. Clin Cancer Res 23: 2593-2604, 2017.

27 Humphrey PA: Histological variants of prostatic carcinoma and their significance. Histopathology 60: 59-74, 2012.

28 Cunningham $\mathrm{D}$ and Zhou $\mathrm{Z}$ : In vitro and in vivo model systems used in prostate cancer research. J Biol Methods 2: e17, 2015.

29 Park SI, Kim SJ, McCauley LK and Gallick GE: Pre-clinical mouse models of human prostate cancer and their utility in drug discovery. Curr Protoc Pharmacol: Chapter 14, Unit 14.15, 2010.

30 Koshida K, Konaka H, Imao T, Egawa M, Mizokami A and Namiki M: Comparison of two in vivo models for prostate cancer: Orthotopic and intratesticular inoculation of $\mathrm{LNCaP}$ or PC3 cells. Int J Urol 11: 1114-1121, 2004. 
31 Greenberg NM, DeMayo F, Finegold MJ, Medina D, Tilley WD, Aspinall JO, Cunha GR, Donjacour AA, Matusik FJ and Rosen JM: Prostate cancer in a transgenic mouse. Proc Natl Acad USA 92: 3439-3443, 1995.

32 Ginrich JR, Barrios RJ, Morton RA, Boyce BF, DeMayo FJ, Finegold MJ, Angelopoulu R, Rosen JM and Greenberg NM: Metastatic prostate cancer in a transgenic mouse. Cancer Res 56: 4096-4102, 1996.

33 Seashols-Williams SJ, Budd W, Clark GC, Wu Q, Daniel R, Dragescu E and Zehner ZE: $m i R-9$ acts as an oncomiR in prostate cancer through multiple pathways that drive tumor progression and metastasis. PLoS One 11: e159601, 2016.

34 Liu M, Zhu H, Yang S, Wang Z, Bai J and Xu N: c-Myc suppressed E-cadherin through $m i R-9$ at the post-transcriptional level. Cell Biol Int 37: 197-202, 2013.

35 Zhuang G, Wu X, Jiang Z, Kasman I, Yao J, Guan Y, Oeh J, Modrusan Z, Bais C, Sampath D and Ferrara N: Tumor secreted $m i R-9$ promotes endothelial cell migration and angiogenesis by activating the JAK-STAT pathway. EMBO J 31: 3513-3523, 2012.

36 Das R, Gregory PA, Fernandes RC, Denis I, Wang Q, Townley SL, Zhao SG, Hanson AR, Pickering MA, Armstrong HK, Lohman NA, Ebrahimie E, Davicione E, Jenkins RB, Kames RJ, Ross AE, Den RB, Klein EA, Chi KN, Ramshaw HS, Williams ED, Zoubeid A, Goodall GJ, Feng FY, Butler LM, Tilley WD and Selth LA: MicroRNA-194 promotes prostate cancer metastasis by inhibiting SOCS2. Cancer Res 77: 1021-1034, 2017.

37 Wu D, Sunkel B, Chen Z, Liu X, Ye Z, Li Q, Grenade C, Ke J, Zhang C, Chen H, Nephew KP, Huang TH, Liu Z, Jin VX and Wang Q: Three-tiered role of the pioneer factor GATA2 in promoting androgen-dependent gene expression in prostate cancer. Nucleic Acids Res 42: 3607-3622, 2014.

38 Chiang YT, Wang K, Fazli L, Qi RZ, Gleave ME, Collins CC, Gout PW and Wang Y: GATA2 as a potential metastasis-driving gene in prostate cancer. Oncotarget 5: 451-461, 2014.

39 Letellier E and Haan S: SOCS2: Physiological and pathological functions. Front Biosci (Elite Ed) 8: 189-204, 2016.

40 Sen B, Peng S, Woods DM, Wistuba I, Bell D, El-Naggar AK, Lai SY and Johnson FM: STAT5A-mediated SOCS2 expression regulates JAK2 and STAT3 activity following c-SRC inhibition in head and neck squamous carcinoma. Clin Cancer Res 18: 127-139, 2012.

41 Ren D, Yang Q, Dai Y, Guo W, Du H, Song L and Peng X: Oncogenic $m i R-210-3 p$ promotes prostate cancer cell EMT and bone metastases via NF-kappaB signaling pathway. Mol Cancer 16: 117, 2017.

42 Park SH, Kim KE, Hwang HY and Kim TY: Regulatory effect of SOCS on NF-kappaB activity in murine monocytes/ macrophages. DNA Cell Biol 22: 131-139, 2003.

43 Gingras S, Paraganas E, de Pauw A, Ihle JN and Murray PJ: Re-examination of the role of suppressor of cytokine signaling 1 (SOCS1) in the regulation of toll-like receptor signaling. J Biol Chem 279: 54702-54707, 2004.

44 Verstrepen L, Carpentier I, Verhelst K and Bevaert R: ABINs: A20 binding inhibitors of NF-kappa B and apoptosis signaling. Biochem Pharmacol 78: 105-114, 2009.

45 Ben-Neriah Y: Pinning NF-kappa B to the nucleus. Mol Cell 12: 1344-1345, 2003.

46 Tsai YC, Chen WY, Siu MK, Tsai HY, Yin JJ, Huang J and Liu YN: Epidermal growth factor receptor signaling promotes metastatic prostate cancer through microRNA-96-mediated down-regulation of the tumor suppressor ETV6. Cancer Letters 384: 1-8, 2017.

47 Hock $\mathrm{H}$ and Shimamura A: ETV6 in hematopoesis and leukemia predisposition. Semin Hematol 54: 98-104, 2017.

48 Taylor BS, Schultz N, Hieronymus H, Gopalan A, Xiao Y, Carver BS, Arora VK, Kaushik P, Cerami E, Reva B, Antipin Y, Mitsiades N, Landers T, Dolgaley I, Major JE, Wilson M, Socci ND, Lash AE, Heguy A, Eastham JA, Scher HI, Reuter VE, Scardino PT, Sander C, Sawyers CL and Gerald WL: Integrative genomic profiling of human prostate cancer. Cancer Cell 18: 11-22, 2010.

49 Wang Q, Dong S, Yao H, Wen L, Qiu H, Qin L, Ma L and Chen S: ETV6 mutation in a cohort of 970 patients with hematologic malignancies. Haematologica 99: e176-178, 2014.

50 Hafliadottir BS, Larne O, Martin M, Persson M, Edsjo A, Biartell A and Ceder Y: Up-regulation of miR-96 enhances cellular proliferation of prostate cancer cells through FOXO1. PLoS One 8: e72400, 2013.

51 Nakamura N, Ramaswamy S, Vazquez F, Signoretti S, Loda M and Sellers WR: Forkhead transcription factors are critical effectors of cell death and cell-cycle arrest downstream of PTEN. Mol Cell Biol 20: 8969-8982, 2000.

52 Dong HY, Chen C, Sun X, Guo P, Vessella RL, Wang RX, Chung LW, Zhou W and Dong JT: FOXO1A is a candidate for the $13 \mathrm{q} 14$ tumor-suppressor gene inhibiting androgen receptor signaling in prostate cancer. Cancer Res 66: 6998-7006, 2006.

53 Ramaswamy S, Nakamura N, Sansal I, Bergeron L and Sellers WR: A novel mechanism of gene regulation and tumor suppression by the transcription factor FKHR. Cancer Cell 2: 81-91, 2002.

54 Liu P, Li S, Gan 1, Kao TP and Huang H: A transcriptionindependent function of FOXO1 in inhibition of androgenindependent activation of the androgen receptor in prostate cancer cells. Cancer Res 68: 10290-10299, 2008.

55 Siu MK, Tsai YC, Chang YS, Yin JJ, Suau F, Chen WY and Liu YN: Transforming growth factor-beta promotes prostate bone metastasis through induction of microRNA-96 and activation of the mTOR pathway. Oncogene 34: 4767-4776, 2015.

56 Ma Y, Yang HZ, Dong BJ, Zou HB, Zhou Y, Kong XM and Huang YR: Biphasic regulation of autophagy by miR-96 in prostate cancer cells under hypoxia. Oncotarget 15: 9169-9182, 2014.

57 Josson S, Gururajan M, Hu P, Shao C, Chu GY, Zhau HE, Liu C, Lao K, Lu CL, Lu YT, Lichterman J, Nandana S, Li Q, Rogatko A, Berel D, Posadas EM, Fazli L, Sareen D and Chung LW: $m i R-409-3 \mathrm{p} /-5 \mathrm{p}$ promotes tumorigenesis, epithelial-tomesenchymal transition, and bone metastasis of human prostate cancer. Clin Cancer Res 20: 4636-4647, 2014.

58 Gururajan M, Josson S, Chu GC, Lu CL, Lu YT, Haga CL, Zhau HE, Liu C, Lichterman J, Duan P, Posadas EM and Chung LW: $m i R-154^{*}$ and miR-379 in the DLK-DIO3 microRNA mega-cluster regulate epithelial to mesenchymal transition and bone metastasis of prostate cancer. Clin Cancer Res 20: 65596569, 2014.

59 Solomon DA, Kim T, Diaz-Martinez LA, Fair J, Elkahloun AG, Harris BT, Toretsky JA, Rosenberg SA, Shukla N, Ladanyi M, Samuels Y, James CD, Yu H, Kim JS and Waldman T: Mutational inactivation of STAG2 causes aneuploidy in human cancer. Science 333: 1039-1043, 2011. 
60 Kim MS, Kim SS, Je EM, Yoo NJ and Lee SH: Mutational and expressional analyses of STAG2 gene in solid cancers. Neoplasma 59: 524-529, 2012.

61 Dougherty GW, Jose C, Gimona M and Cutler ML: The RSU1PINCH1-ILK complex is regulated by RAS activation in tumor cells. Eur J Cell Biol 87: 721-734, 2008.

62 Maddika S, Ande SR, Panigrahi S, Paranjothy T, Weglarczyk $\mathrm{K}$, Zuse A, Eshraghi M, Manda KD, Wiechec E and Los M: Cell survival, cell death and cell-cycle pathways are interconnected: implications for cancer therapy. Drug Resist Update 10: 13-29, 2007.

63 Kurata A, Katayama R, Watanabe T, Tsuruo T and Fujita N: TUSC4/NPRL2, a novel PDK1-interacting protein, inhibits PDK1 tyrosine phosphorylation and its downstream signaling. Cancer Sci 99: 1827-1837, 2008.

64 Iwata S, Takenobu H, Kageyama H, Koseki H, Ishii T, Nakazawa A, Tatezaki A, Tatezaki S, Nakagawara A and Kamiio T: Polycomb group molecule $\mathrm{PHC} 3$ regulates polycomb complex composition and prognosis of osteosarcoma. Cancer Sci 101: 1647-1652, 2010.

65 Maxwell PH, Wiesenger MS, Chang GW, Clifford SC, Vaux EC, Cockman ME, Wykoff CC, Pugh CW, Maher ER and Ratcliffe PJ: The tumor suppressor VHL targets hypoxiainducible factors for oxygen-dependent proteolysis. Nature 399: 271-275, 1999

66 Edlund S, Bu S, Schuster N, Aspenström, Heuchel R, Heldin NE, ten Dijke P, Heldin $\mathrm{CH}$ and Landström M: Transforming growth factor-beta 1 (TGF-beta)-induced apoptosis of prostate cancer cells involves SMAD7-dependent activation of $\mathrm{p} 38$ by TGF-beta-activated kinase 1 and mitogen-activated protein kinase kinase 3. Mol Biol Cell 14: 529-544, 2003.

67 Liu X, Chen Q, Yan J, Wang Y, Zhu C, Chen C, Zhao X, Xu M, Sun Q, Deng R, Zhang H, Qu Y, Huang J, Jiang B and Yu B: miRNA-296-3p-ICAM-1 axis promotes metastasis of prostate cancer by possible enhancing survival of natural killer cell-resistant circulating tumor cells. Cell Death Dis 4: e928, 2013.

68 Hanna M: Role of natural killer cells in control of cancer metastasis. Cancer Metastasis Rev 1: 45-64, 1982.

69 Chong AS, Boussy IA, Jiang XK, Lamas M and Graf LH Jr.: CD54/ICAM-1 is a co-stimulator of NK cell-mediated cytotoxicity. Cell Immunol 157: 92-105, 1994.

70 Xie H, Li L, Zhu G, Dang Q, Ma Z, He D, Chang L, Song W, Chang HC, Krolewski JP, Nastiuk KL, Yeh S and Chang C: Infiltrated pre-adipocytes increase prostate cancer metastasis via modulation of the miR-301a/androgen receptor (AR)/TGFbeta1/ SMAD/MMP9 signals. Oncotarget 6: 12326-12329, 2015.

71 Nam RK, Amemiya Y, Benatar T, Wallis CJ, Stojcic-Bendavid J, Bacopulos S, Sherman C, Sugar L, Naeim M, Yang W, Zhang A, Klotz LH, Narod SA and Seth A: Identification and validation of five microRNA signature of prostate cancer recurrence and metastasis: A cohort study. J Cancer 6: 11601171,2015

72 Qi W, Gao S and Wang Z: Transcriptional regulation of the TGF-beta1 promoter by androgen receptor. Biochem $\mathrm{J} 416$ 453-462, 2008

73 Derynk R, Zhang Y and Feng XH: SMADs: Transcriptional activators of TGF-beta responses. Cell 95: 737-740, 1998.

74 Heinlein CA and Chang C: Androgen receptor in prostate cancer. Endocr Rev 25: 276-308, 2004.
75 Rosen ED and MacDougald OA: Adipocyte differentiation from the inside out. Nat Rev Mol Cell Biol 7: 885-896, 2006.

76 Collins AT, Berry TA, Hyde C, Stower MJ and Maitland NJ: Prospective identification of tumorigenic prostate cancer stem cells. Cancer Res 65: 10946-10951, 2005.

77 Patrawala L, Cahoun T, Schneider-Broussard R, Li H, Bhatia B, Tang S, Reilly JG, Chandra D, Zhou J, Claypool K, Coghlan L and Tang DG: Highly purified CD44+ prostate cancer cells from xenograft human tumors are enriched in tumorigenic and metastatic progenitor cells. Oncogene 25: 1696-1708, 2006.

78 Bucay N, Sekhon K, Yang T, Majid S, Shahryari V, Hsieh C, Mitsui Y, Deng G, Tabatabai Z, Yamamura S, Calin GA, Dahiya R, Tanaka Y and Saini S: MicroRNA-383 located in frequently deleted chromosomal locus 8p22 regulates CD44 in prostate cancer. Oncogene 36: 2667-2679, 2017.

79 Liu C, Kelnar K, Liu B, Chen X, Calhoun-Davis T, Li H, Patrawala L, Yan H, Jeter C, Honorio S, Wiggins JF, Bader Ag, Fagin R, Brown D and Tang DG: The microRNA miR-34a inhibits prostate cancer stem cells and metastasis by directly repressing CD44. Nat Med 17: 211-215, 2011.

80 Saini S, Majid S, Shahryari V, Arora S, Yamamura S, Chang I, Zaman MS, Deng G, Tanaka Y and Dahiva R: miRNA-708 control of CD44 (+) prostate cancer-initiating cells. Cancer Res 72: 3618-3630, 2012.

81 Yang K, Handorean AM and Iczkowski KA: MicroRNAs 373 and 520c are down-regulated in prostate cancer, suppress CD44 translation and enhance invasion of prostate cancer cells in vitro. Int J Clin Exp Pathol 2: 361-369, 2009

82 Iczkowski KA: Cell adhesion molecule CD44: Its functional role in prostate cancer. Am J Transl Res 3: 1-7, 2010.

83 Wang L, Song G, Tan W, Qi M, Zhang L, Chan J, Yu J, Han J and Han B: miR-573 inhibits prostate cancer metastasis by regulating epithelial-mesenchymal transition. Oncotarget 6 : 35978-35990, 2015

84 Nguyen AH, Tremblay M, Haigh K, Koumakpayi ICH, Paquet M, Pandolfi PP, Mes-Masson AM, Saad F, Haigh JJ and Brouchard M: GATA3 antagonizes cancer progression in PTEN-deficient prostates. Human Mol Genet 22: 2400-2410, 2013.

85 Tomlinson DC, Baxter EW, Loadman PM, Hull MA and Knowles MA: FGFR1-induced epithelial to mesenchymal transition through MAPK7PLCgamma/COX2-mediated mechanisms. PLoS One 7: e38972, 2012.

86 Peng X, Guo W, Liu T, Wang X, Tu X, Xiong D, Chen S, Lai Y, Du H, Chen G, Liu G, Tang Y, Huang S and Zou X: identification of miRs-143 and-145 that are associated with bone metastasis of prostate cancer and involved in regulation of EMT. PLoS One 6: e20341, 2011.

87 Sachdeva M and Mo YY: miR-145-mediated suppression of cell growth, invasion and metastasis. Am J Transl Res 2: 170-189, 2010.

88 Zhou C, Nitschke AM, Xiong W, Zhang Q, Tang Y, Boch M, Elliott S, Zhu Y, Bazzone L, Yu D, Weldon CB, Schiff R, McLachlan JA, Beckman BS, Wiese TE, Nephew KP, Shan B, Burrow ME and Wang G: Proteomic analysis of tumor necrosis factor-alpha resistant human breast cancer cells reveals MEK5/ERK5-mediated epithelial-mesenchymal transition phenotype. Breast Cancer Res 10: R105, 2008.

89 Clape C, Fritz V, Henriquet C, Apparailly F, Fernandez PL, Iborra F, Avances C, Villalba M, Culine S and Fajas L: miR143 interferes with ERK5 signaling, and abrogates prostate cancer progression in mice. PLoS One 4: e7542, 2009. 
90 Williams LV, Veliceasa D, Vinokour E and Volpert OV: $m i R$ $200 b$ inhibits prostate cancer EMT, growth and metastasis. PLoS One 8: e83991, 2013.

91 Kong D, Li Y, Wang Z, Banerjee S, Ahmad A, Kim HR and Sarkar FH: $m i R-200$ regulates PDGF-D-mediated epithelialmesenchymal transition, adhesion and invasion of prostate cancer cells. Stem cells 27: 1712-1721, 2009.

92 Chen Q, Zhao X, Zhang H, Yuan H, Zhu M, Sun Q, Lai X, Wang Y, Huang J, Yan J and Ju J: miR-130b suppresses prostate cancer metastasis through downregulation of MMP2. Mol Carcinog 54: 1292-1300, 2015.

93 Kessenbrock K, Plaks V and Werb Z: Matrix metalloproteinases: Regulators of the tumor microenvironment. Cell 141: 52-67, 2010.

94 Chen W, Liu Y, Chen H, Ning H and Ding K: Loss of $m i R-$ $449 a$-caused PrLZ overexpression promotes prostate cancer metastasis. Int J Oncol 51: 435-444, 2017.

95 Wang R, Xu J, Mabjeesh N, Zhu G, Zhou J, Ami M, He D, Marshakk FF, Zhau HE and Chung LW: PrLZ is expressed in normal prostate development and in human prostate cancer progression. Clin Cancer Res 13: 6040-6048, 2007.

96 Li L, Zhang D, Zhang L, Zhu G, Sun Y, Wu K, Wang X and He D: PrLZ expression is associated with the progression of prostate cancer LNCaP cells. Mol Carcinog 48: 432-40, 2009.

97 Li L, Xie H, Liang L, Gao Y, Zhang D, Fang L, Lee So, Luo J, Chen X, Wang X, Chang LS, Yeh S, Wang Y, He D and Chang $\mathrm{C}$ : Increased PRLZ-mediated androgen receptor transactivation promotes prostate cancer growth at castration-resistant stage. Carcinogenesis 34: 257-267, 2013.

98 Zoni E, van der Horst G, van de Marbel AF, Chen L, Rane JK, Pelger RC, Collins AT, Visakorpi T, Snaar-Jagalska BE, Maitland NJ and van der Pluijm G: $m i R-25$ modulates invasiveness and dissemination of human prostate cancer cells via regulation of alphav-alpha6-integrin expression. Cancer Res 75: 2326-2336, 2015.

99 Douville J, Beaulieu R and Balicki D: ALDH as a functional marker of cancer stem and progenitor cells. Stem Cells Dev 18: 17-25, 2009.

100 Cruz-Monserrate Z and O'Connor KL: Integrin alpha 6 beta 4 promotes migration, invasion through TIAM1 and subsequent RAC activation. Neoplasia 10: 408-417, 2008.

101 Neijari M, Hafdi Z, Gouysse G, Fiorentino M, Beatrix O, Dumortier J, Pourreyron C, Barozzi C, D’Errico A, Grigioni WF and Scoazec JY: Expression, regulation and function of alpha $\mathrm{V}$ integrins in hepatocellular carcinoma: An in vivo and in vitro study. Hepatology 36: 418-426, 2002.

102 Drabsch Y, He S, Zhang L, Snaar-Jagalska BE and ten Dijke P: Transforming growth factor-beta signalling controls human breast cancer metastasis in a zebrafish xenograft model. Breast Cancer Res 15: R106, 2013.

103 Liu YN, Yin J, Barrett B, Sheppard-Tillman H, Li D, Casey OM, Fang L, Hynes PG, Ameri AH and Kelly K: Loss of androgen-regulated microRNA 1 activates SRC and promotes prostate cancer bone metastasis. Mol Cell Biol 35: 1940-1951, 2015.

104 Martens-Uzunova ES, Jalaya SE, Dites NF, van Leenders GJ, Moeller S, Trapman J, Bangma CH, Litman T, Visakorpi T and Jenster G: Diagnostic and prognostic features from the small non-coding RNA transcriptome in prostate cancer. Oncogene 31: 978-991, 2012.
105 Varkaris A, Katsiampoura AD, Araujo JC, Gallick GE and Corn PG: SRC signaling pathways in prostate cancer. Cancer Metastasis Rev 33: 595-606, 2014.

106 Yin JJ, Zhang L, Munasinghe J, Linnolla RI and Kelly K: Cediranib/AZD2171 inhibits bone and brain metastasis in a preclinical model of advanced prostate cancer. Cancer Res 70: 8662-8673, 2010.

107 Chang YS, Chen WY, Yin JJ, Sheppard-Tillman H, Huang J and Liu YN: EGF receptor promotes prostate cancer bone metastasis by down-regulating $m i R-1$ and activating TWIST1. Cancer Res 75: 3077-386, 2015.

108 Takeshita F, Patrawala L, Osaki M, Takahashi RU, Yamaamoto Y, Kosaka N, Kawamata M, Kelnar K, Bader AG, Brown D and Ochiya T: Systemic delivery of synthetic microRNA-16 inhibits the growth of metastatic prostate tumors via downregulation of multiple cell-cycle genes. Mol Ther 18: 181-187, 2010.

109 Cai S, Chen R. Li X, Cai Y, Ye Z, Li S, Li J, Huang H, Peng S, Wang J, Tao Y, Huang H, Wen X, Mo J, Den Z, Wang J, Zhang Y, Gao X and Wen X: Downregulation of microRNA23a suppresses prostate cancer metastasis by targeting the PAK6-LIMK1 signaling pathway. Oncotarget 6: 3904-3917, 2015.

110 Liu X, Busby J, John C, Wie J, Yuan X and Lu ML: Direct interaction between AR and PAK6 in androgen-stimulated PAK6 activation. PLoS One 8: e77367, 2013.

111 Ye DZ and Field J: PAK signaling in cancer. Cell Logist 2: 105116, 2012.

112 Edwards DC and Gill GN: Structural features of LIM kinase that control effects on the actin cytoskeleton. J Biol Chem 274: 11352-11361, 1999.

113 Prunier C, Prudent R, Kapur R, Sadoul K and Lafanechiere L: LIM kinases. Cofilin and beyond. Oncotarget 8: 41749-41763, 2017.

114 Arber S, Barbayannis FA, Hanser H, Schneider C, Stanyon CA, Bernard $\mathrm{O}$ and Caroni $\mathrm{P}$ : Regulation of actin dynamics through phosphorylation of cofilin by LIM-kinase. Nature 393: 805-809, 1998.

115 Qin J, Wu SP, Creighton CJ, Dai F, Xie X, Cheng CM, Froloy A, Ayala G, Lin X, Feng XH, Ittmann MM, Tsai SJ, Tsai MJ and Tsai SY: COUP-TFII inhibits TGF- $\beta$-induced growth barrier to promote prostate tumorigenesis. Nature 493: 236-240, 2013.

116 Lin S-C, Kao C-K, Lee H-J, Creighton CJ, Ittmann MM, Shaw JT, Tsai SY and Tsai M-J: Dysregulation of miRNAs-COUPTFII-FOXM1-CENPF axis contributes to the metastasis of prostate cancer. Nat Commun 7: 11418, 2016.

117 Kalin TV, Wang IC, Ackerson TJ, Major ML, Detrisac CJ, Kalnichenko VV, Lyubimov A and Costa RH: Increased levels of FOXM1 transcription factor accelerate development and progression of prostate carcinomas in both TRAMP and LADY transgenic mice. Cancer Res 66: 1712-1720, 2006.

118 Aytes A, Mitrofanova A, Lefebvre C, Alvarez MJ, CastilloMartin M, Zheng T, Eastham JA, Gopalan A, Pienta KJ, Shen MM, Califano A and Abate-Shen C: Cross-species regulatory network analysis identifies a synergistic interaction between FOXM1 and CENPF that drives prostate cancer malignancy. Cancer Cell 25: 638-651, 2014.

119 Colden M, Dar AA, Saini S, Dahiya PV, Shahryari V, Yamamura S, tanaka Y, Stein G, Dahiya R and Majid S: MicroRNA-466 inhibits tumor growth and bone metastasis in 
prostate cancer by direct regulation of osteogenic transcription factor RUNX2. Cell Death Dis 8: e2572, 2017.

120 Pratap J, Lian JB, Jarved A, Barnes GL, van Winen AJ, Stein JL and Stein GS: Regulatory roles of RUNX2 in metastatic tumor and cancer cell interactions with bone. Cancer Metastasis Rev 25: 589-600, 2006.

121 Pratap J, Javed A, Lanquino LR, van Wijnen AJ, Stein JL, Stein GS and Lian JB: The RUNX2 osteogenic transcription factor regulates matrix metalloproteinase 9 in bone metastatic cancer cells and controls cell invasion. Mol Cell Biol 25: 8581-8591, 2005.

122 Ishteiwy RA, Ward TM, Dykxhoorn DM and Burnstein KL: The microRNA-23b/-27b cluster suppresses the metastatic phenotype of castration-resistant prostate cancer cells. PLos One 7: e52106, 2012.

123 Rice MA, Ishteiwy RA, Magani F, Udayakumar T, Reiner T, Yates TJ, Miller P, Perez-Stable C, Rai P, Verdun R, Dykxhoorn DM and Burnstein KL: The microRNA-23b/-27b cluster suppresses prostate cancer metastasis via Huntingtin-interacting protein 1-related. Oncogene 35: 4752-4761, 2016.

124 Gottfried I, Ehrlich M and Ashery U: The SLA2P/HIP1R family: Similar structure, similar function in endocytosis? Biochem Soc Trans 38: 187-191, 2010.

125 Zhang H, Qi S, Zhang T, Wang A, Liu R, Guo J, Wang Y and Xu F: MiR-188-5p inhibits tumor growth and metastasis in prostate cancer by repressing LAPTM4B expression. Oncotarget 6: 6092-6104, 2015.

126 Meng Y, Wang L, Chen D, Chang Y, Zhang M, Xu JJ, Zhou R and Zhang QY: LAPTM4B: An oncogene in various solid tumors and its functions. Oncogene 35: 6359-6365, 2016.

127 Yang H, Xiong FX, Lin M, Yang Y, Nie X and Zhou RL: LAPTM4B-35 overexpression is a risk factor for tumor recurrence and poor prognosis in hepatocellular carcinoma. $\mathrm{J}$ Cancer Res Clin Oncol 136: 275-281, 2010.

128 Yang Y, Yang H, McNutt MA, Xiong F, Nie X, Li L and Zhou $\mathrm{R}$ : LAPTM4B overexpression is an independent prognostic marker in ovarian carcinoma. Oncol Rep 20: 1077-1083, 2008.

129 Zhou L, He XD, Chen J, Cui QC, Qu Q, Rui JA and Zhao YP: Overexpression of LAPTM4B-35 closely correlated with clinicopathological features and post-resectional survival of gallbladder carcinoma. Eur J Cancer 43: 809-815, 2007.

130 Zhou L, He XD, Cui QC, Zhou WX, Qu Q, Zhou RL, Rui JA and Yu JC: Expression of LAPTM4B-35: A novel marker of progression, invasiveness and poor prognosis of extrahepatic cholangiocarcinoma. Cancer Lett 264: 209-217, 2008.

131 Guo J, Wang M and Liu X: MicroRNA-195 suppresses tumor cell proliferation and metastasis by directly targeting $B C O X 1$, a novel gene overexpressed in prostate carcinoma. J Exp Clin Cancer Res 34: 91, 2015.

132 Song J, Yang W, Shih IeM, Zhang Z and Bai J: Identification of $B C O X 1$, a novel gene overexpressed in breast cancer. Biochim Biophys Acta 1760: 62-69, 2006.

133 Liu T, Zhang XY, He XH, Geng JS, Liu Y, Kong DJ, Shi QY, Liu F, Wei W and Pang D: High levels of BCOX1 expression are associated with poor prognosis in patients with invasive ductal carcinomas of the breast. PLoS One 9: e86952, 2014.

134 Guo J, Liu X and Wang M: miR-503 suppresses tumor cell proliferation and metastasis by directly targeting RNF31 in prostate cancer. Biochem Biophys Res Commun 464: 1302-1308, 2015.

135 Kirisako T, Kamei K, Murata S, Kato M, Fukumoto H, Kanie M, Sano S, Tokunaga F, Tanaka K and Iwai K: A ubiquitin ligase complex assembles linear polyubiquitin chains. EMBO J 25: 4877-4887, 2006.

136 Walczak H, Iwai K and Dikic I: Generation and physiological role of linear polyubiquitin chains. BMC Biol 10: 23, 2012.

137 Stieglitz B, Rana RR, Koliopoulos MG, Morris-Davies AC, Schaeffer V, Christodoulou E, Howell S, Brown NR, Dikic I and Rittinger K: Structural basis for ligase-specific conjugation of linear ubiquitin chains by HOIP. Nature 503: 422-426, 2013.

138 Zhu J, Zhao C, Zhuang T, Jonsson P, Sinha I, Williams C, Strömblad $\mathrm{S}$ and Dahlman-Wright K: RING finger protein 31 promotes p53 degradation in breast cancer cells. Oncogene 35 : 1955-1964, 2016.

139 Zhu J, Zhuang T, Yang H, Li X, Liu H and Wang H: Atypical ubiquitin ligase RNF31: The nuclear factor modulator in breast cancer. BMC Cancer 16: 538, 2016.

140 Yang J, LuC, Wie J, Guo Y, Liu W, Luo L, Fisch G and Li X: Inhibition of KPNA4 attenuates prostate cancer metastasis. Oncogene 36: 2868-2878, 2017.

141 Lam J, Takeshita S, Barker JE, Kanagawa O, Ross FP and Teitelbaum SL: TNF-alpha induces osteoclastogenesis by direct stimulation of macrophages exposed to permissive levels of RANK ligand. J Clin Invest 106: 1481-1488, 2000.

142 Kobayashi K, Takahashi N, Jimi E, Udagawa N, Takami M, Kotake S, Nakagawa N, Kinosaki M, Yamaguchi K, Shima N, Yasuda H, Morinaga T, Higashio K, Martin TJ and Suda T: Tumor necrosis factor alpha stimulates osteoclast differentiation by a mechanism independent of the ODF/RANKL-RANK interaction. J Exp Med 191: 275-286, 2000.

143 Ostuni R, Kratochvill F, Murray PJ and Natoli G: Macrophages and cancer: from mechanisms to therapeutic implications. Trends Immunol 36: 229-239, 2015.

144 Liu C, Liu R, Zhang D, Deng Q, Liu B, Chao HP, Rycaj K, Takata Y, Lin K, Lu Y, Zhong Y, Krolewski J, Shen J and Tang DG: MicroRNA-141 suppresses prostate cancer stem cells and metastasis by targeting a cohort of pro-metastatic genes. Nat Commun 8: 14270, 2017.

145 Varambally S, Dhanasekaran SM, Zhou M, Barette TR, KumarSinha C, Sanda MG, Ghosh D, Pienta KJ, Sewalt RG, Otte AP, Rubin MA and Chinnaiyan AM: The polycomb group protein $\mathrm{EZH} 2$ is involved in progression of prostate cancer. Nature 419 : 624-629, 2002.

146 Rottner K and Stradal TE: Actin dynamics and turnover in cell motility. Curr Opin Cell Biol 23: 569-578, 2011.

147 Friedl $\mathrm{P}$ and Alexander S: Cancer invasion and the microenvironment: Plasticity and reprocity. Cell 147: 992-1009, 2011.

148 Sanz-Moreno V and Marshall CJ: The plasticity of cytoskeletal dynamics underlying neoplastic cell migration. Curr Opin Cell Biol 22: 690-696, 2010.

149 Huang S, Wa Q, Pan J, Peng X, Ren D, Huang Y, Chen X and Tang Y: Downregulation of miR-141-3p promotes bone metastasis via activating NF-kappaB signaling in prostate cancer. J Exp Clin Cancer Res 36: 173, 2017.

150 Xie P: TRAF molecules in cell signaling and in human diseases. J Mol Signal 8: 7, 2013.

151 Siu MK, Abou-Kheir W, Yin JJ, Chang YS, Barrett B, Suau F, Casey O, Chen WY, Fang L, Hynes P, Hsieh YY, Liu YN, Huang $\mathrm{J}$ and Kelly K: Loss of EGFR signaling promotes bone metastasis and tyrosine kinase inhibitors resistance. Oncotarget 5: 3770-3784, 2014. 
152 Xiang J, Bian C, Wang H, Huang S and Wu D: miR-203 downregulates RAP1A and suppresses cell proliferation, adhesion and invasion in prostate cancer. J Exp Clin Cancer Res 34: 8, 2015.

153 Saini S, Majid S, Yamamura S, Tabatabai L, Suh SO, Shahryari V, Chen Y, Deng G, Tanaka Y and Dahiya R: Regulatory role of $m i R-203$ in prostate cancer progression. Clin Cancer Res 17: 5287-5298, 2011.

154 Bos JL: Linking Rap to cell adhesion. Curr Opin Cell Biol 17: 123-128, 2005

155 Fujita H, Fukuhara S, Sakurai A, Yamagishi A, Kamioka Y, Nakaoka Y, Masuda M and Mochizuki N: Local activation of RAP1 contributes to directional vascular endothelial cell migration accompanied by extension of microtubules on which RAPL, a RAP1-associating molecule, localizes. J Biol Chem 280: 5022-5031, 2005.

156 Altieri DC, Languino LR, Lian JB, Stein JL, Leav I, van Wijnen AJ, Jiang T and Stein GS: Prostate cancer regulatory networks. J Cell Biochem 107: 845-852, 2009.

157 Brubaker KD, Vessella RL, Brown LG and Corey E: Prostate cancer expression of runt-domain transcription factor RUNX2, a key regulator of osteoblast differentiation and function. Prostate 56: 13-22, 2003.

158 Akech J, Wixted JJ, Bedard K, van der Deen M, Hussain S, Guise TA, van Wijnen AJ, Stein JL, Lanquino LR, Altieri DC, Pratap J, Keller E, Stein GS and Lian JB: RUNX2 association with progression of prostate cancer in patients: mechanisms mediating bone osteolysis and osteoblastic lesions. Oncogene 29: 811-821, 2010.

159 Hailer A, Grunewald TG, Orth M, Reiss C, Kneitz B, Spahn M and Butt E: Loss of tumor suppressor miR-203 mediates overexpression of LIM and SH3 protein 1 (LASP1) in high-risk prostate cancer thereby increasing cell proliferation and migration. Oncotarget 5: 4144-4153, 2014.

160 Grunewald TG and Butt E: The LIM and SH3 domain protein family: Structural proteins or signal transducers or both? Mol Cancer 7: 31, 2008.

161 Tomasetto C, Moog-Lutz C, Regnier CH, Schreiber V, Basset $P$ and Rio MC: LASP-1 (MLN 50) defines a new LIM protein subfamily characterized by the association of LIM and SH3 domains. FEBS Lett 373: 245-249, 1995.

162 Broderick JA and Zamore PD: MicroRNA therapeutics. Gene Ther 18: 1104-1110, 2011.

163 Gambari R, Brognara E, Spandidos DA and Fabbri E: Targeting oncomiRNAs and mimicking tumor suppressor miRNAs: New trends in the development of miRNA therapeutic strategies in oncology. Int J Oncol 49: 5-32, 2016.

164 Ling H, Fabbri M and Calin GA: MicroRNAs and other noncoding RNAs as targets for anticancer drug development. Nat Rev Drug Discov 12: 847-865, 2013.

165 Rupaimoole R and Slack FJ: MicroRNA therapeutics: Towards a new era for the management of cancer and other diseases. Nat Rev Drug Discov 16: 203-222, 2017.

$166 \mathrm{Li} \mathrm{Z}$ and Rana TM: Therapeutic targeting of microRNAs: Current status and future challenges. Nat Rev Drug Discov 13: $622-638,2014$

167 Garafalo M, Leva GD and Croce CM: MicroRNAs as anticancer therapy. Curr Pharm Des 20: 5328-5335, 2014.

168 Malek A, Merkel O, Fink L, Czubayko F, Kissel T and Aigner A: In vivo pharmakinetics, tissue distribution and underlying mechansisms of various PE(-PEG) siRNA complexes. Toxicol Appl Pharmacol 236: 97-108, 2009.

169 Jung S, Lee SH, Mok H, Chung HJ and Park TG: Gene silencing efficiency of siRNA-PEG conjugates: Effect of PEGylation site and PEG molecular weight. J Control Release 144: 296-331, 2010.

170 Mui BL, Tam YK, Jajaraman M, Ansell SM, Du X, Tam YY, Lin PJ, Chen S, Narayanannair JK, Rajeev KG, Manoharan M, Akinc A, Maier MA, Cullis P, Madden TD and Hope MJ: Influence of polyethylene glycol lipid desorption rates on pharmacokinetics and pharmacodynamics of siRNA lipid nanoparticles. Mol Ther Nucleic Acids 2: e139, 2013.

171 Wang AZ, Langer R and Farokhazad OC: Nanoparticle delivery of cancer drugs. Annu Rev Med 63: 185-198, 2012.

172 Zimmermann TS, Lee AC, Akinc A, Bramlage B, Bumcrot D, fedorulk MN, Harborth J, Heyes JA, Jeffs LB, John M, Judge AD, Lam K, McClintotock K, Nechev LV, Palmer LR, Racie T, Roehl I, Seiffert S, Shanmugam S, Sood V, Soutschek J, Toudjarsja I, Wheat AJ, Yaworski E, Zedalis W, Koteliansky V, Manoharan M, Vornlocher HP and MacLachlan I: RNAi-mediated gene silencing in non-human primates. Nature 441: 111-114, 2006.

173 Rozema DB, Lewis DL, Wakefield DH, Wong SC, Klein JJ, Roesch PL, Bertin SL, Reppen TW, Chu Q, Blokhin AV, Hagstrom JE and Wolff JA: Dynamic polyconjugates for targeted in vivo delivery of siRNA to hepatocytes. Proc Natl Acad Sci USA 104: 12982-12987, 2007.

174 Basha G, Novobrantseva TI, Rosin N, Tam YY, Hafez IM, Wong MK, Sugo T, Ruda VM, Qin J, Klebanov B, Ciufolini M, Akinc A, Tam YK, Hope MJ and Cullis PR: Influence of cationic lipid composition on gene silencing properties of lipid nanoparticle formulations of siRNA in antigen-presenting cells. Mol Ther 19: 2186-21200, 2011.

175 Lee H, Lytton-Jean AK, Chen Y, Love KT, Park AI, Karagiannis ED, Sehgal A, Querbes W, Zurenko CS, Jayaraman M, Peng CG, Charisse k, Borodovsky A, Manoharan M, Donahoe JS, Truelove J, Nahrendorf M, Langer R and Anderson DG: Molecularly selfassembled nucleic acid nanoparticles for targeted in vivo siRNA delivery. Nat Nanotechnol 7: 389-393, 2012.

176 Wong SC, Klein JJ, Hamilton HL, Chu Q, Frey CL, Trubetskoy VS, Hegge J, Wakefield D, Rozema and Lewis DL: Co-injection of a targeted, reversibly masked endosomolytic polymer dramatically improves the efficacy of cholesterol-conjugated small interfering RNAs in vivo. Nucl Acid Ther 22: 380-390, 2012.

177 Kanasty R, Dorkin JR, Vegas A and Anderson D: Delivery materials for siRNA therapeutics. Nat Mater 12: 967-977, 2013.

178 Smith D, Schüller V, Engst C, Rädler J and Liedl T: Nucleic acid nanostructures for biomedical aplications. Nanomedicine 8: 105-121, 2013.

179 Wittrup A and Lieberman J: Knocking down disease: A progress report on siRNA therapeutics. Nat Rev Genetics 16: 543-552, 2015.

180 Farokhzad OC, Jon S, Khademhosseini A, Tran TN, Lavan DA and Langer R: Nanoparticle-aptamer bioconjugates: A new approach for targeting prostate cancer cells. Cancer Res 64: 7668-7672, 2004.

181 Song E, Zhu P, Lee SK, Chowdury D, Kussmann S, Dykxhoorn DM, Feng Y, Palliser D, Weiner DB, Shankar P, Marasco WA and Lieberman J: Antibody mediated in vivo delivery of small interfering RNAs via cell-surface receptors. Nat Biotechnol 23: 709-717, 2005. 
182 Chu TC, Twu KY, Ellington AD and Levy M: Apatmermediated siRNA delivery. Nucleic Acids Res 34: e73, 2006.

183 Schneider B, GroteM, John M, Haas A, Bramlage B, Ickenstein LM, Jahn-Hofmann K, Bauss F, Cheng W, Croasdale R, Daub K, Dill S, Hoffmann E, Lau W, Burtscher H, Ludtke JL, Metz S, Mundigl O, Neal Zc, Scheuer W, Stracke J, Herweijer H and Brinkmann U: Targeted siRNA delivery and mRNA knockdown mediated by bispecific digoxigenin antibodies. Mol Ther Nucleic Acids 18: e46, 2012.

184 Cuellar TL, Barnes D, Nelson C, Tanquay J, Yu SF, Wen X, Scales SJ, Gesch J, Davis D, van Brabant Smith A, Leake D, Vandlen R and Siebel CW: Systemic evaluation of antibody-mediated siRNA delivery using an industrial platform of THIOMAB-siRNA conjugates. Nucleic Acids Res 43: 1189-11293, 2015.

185 Bäumer N, Appel N, Terheyden L, Buchholz F, Rössig C, Müller-Tidow C, Berdel WE and Bäumer S: Antibody-coupled siRNA as an efficient method for in vivo mRNA knockdown. Nat Protoc 11: 22-36, 2016.

186 Diao Y, Liu J, Ma Y, Su M, Zhang H and Hao X: A specific aptamer-cell penetrating peptides complex delivered siRNA efficiently and suppressed prostate tumor growth in vivo. Cancer Biol Ther 17: 498-506, 2016.

187 Mehrabadi FS, Adelmann J, Gupta S, Wedepohl S, Calderon M, Brinkmann U and Haag R: Bispecific antibodies for targeted delivery of dendritic polyglycerol (dPG) prodrug conjugates. Curr Cancer Drug Targets 16: 639-649, 2016.

188 Palanca-Wessels MC, Booth GC, Convertine AJ, Lundy BB, Berguig GY, Press MF, Stayton PS and Press OW: Antibody targeting facilitates effective intratumoral siRNA nanoparticle delivery of HER2-overexpressing cells. Oncotarget 7: 95619575, 2016.

189 Roberts TC, Ezzat K, Andaloussi S and Weinberg MS: Synthetic siRNA delivery: Progress and prospects. Meth Mol Biol 1364: 291-310, 2016.
$190 \mathrm{Wu}$ M, Zhao H, Guo L, Wang Y, Song J, Zhao X, Li C, Hao L, Wang D and Tang J: Ultrasound-mediated nanotube destruction (UMND) facilitates the delivery of A10.3.2 aptamer targeted and siRNA-loaded cationic nanobubbles for therapy of prostate cancer. Drug Del 25: 226-240, 2018.

191 Guo X, MacKay JA and Szoka FC Jr.: Mechanism of pHtriggered collapse of phosphatidylethanolamine liposomes stabilized by an ortho ester polyethyleneglycol lipid. Biophys J 84: 1784-1795, 2003.

192 Shin J, Shum P and Thompson DH: Acid-triggered release via dePEGylation of DOPE liposomes containing acid-labile vinyl ether PEG-lipids. J Control Release 91: 187-200, 2003.

193 Derossi D, Joliot AH, Chassaing G and Prochiantz A: The third helix of antennapedia homeodomain translocates through biological membranes. J Biol Chem 269: 10444-10450, 1994.

194 Thoren PE, Persson D, Isakson P, Goksör M, Onfelt A and Norden B: Uptake of analogs of penetratin, TAT(48-60) and oligoarginine in live cells. Biochem Biophys Res Commun 307: 100-107, 2003.

195 Copolovici DM, Langel K, Eriste E and Langel U: Cellpenetrating peptides. Design, synthesis, and applications. ACS Nano 8: 1972-1994, 2014.

196 Zorko M and Langel U: Cell-penetrating peptides: mechanism and kinetics of cargo delivery. Adv Drug Deliv Rev 57: 529$545,2005$.

197 Haas AK, Maisel D, Adelmann J, von Schwerin C, Kahnt I and Brinkmann U: Human-protein-derived peptides for intracellular delivery of biomolecules. Biochem J 442: 583-593, 2012.

Received September 26, 2018

Revised November 8, 2018

Accepted November 23, 2018 